Review

\title{
Ebselen and Analogues: Pharmacological Properties and Synthetic Strategies for Their Preparation
}

\author{
Claudio Santi (D), Cecilia Scimmi and Luca Sancineto *
}

check for

updates

Citation: Santi, C.; Scimmi, C.;

Sancineto, L. Ebselen and Analogues: Pharmacological Properties and Synthetic Strategies for Their Preparation. Molecules 2021, 26, 4230. https:// doi.org/

$10.3390 /$ molecules 26144230

Academic Editor: Arun Sharma

Received: 15 June 2021

Accepted: 9 July 2021

Published: 12 July 2021

Publisher's Note: MDPI stays neutral with regard to jurisdictional claims in published maps and institutional affiliations.

Copyright: (c) 2021 by the authors. Licensee MDPI, Basel, Switzerland. This article is an open access article distributed under the terms and conditions of the Creative Commons Attribution (CC BY) license (https:/ / creativecommons.org/licenses/by/ $4.0 /)$.
Group of Catalysis and Green Organic Chemistry, Department of Pharmaceutical Sciences, University of Perugia Via del Liceo 1, 06122 Perugia, Italy; claudio.santi@unipg.it (C.S.); cecilia.scimmi@studenti.unipg.it (C.S.)

* Correspondence: luca.sancineto@unipg.com

\begin{abstract}
Ebselen is the leader of selenorganic compounds, and starting from its identification as mimetic of the key antioxidant enzyme glutathione peroxidase, several papers have appeared in literature claiming its biological activities. It was the subject of several clinical trials and it is currently in clinical evaluation for the treatment of COVID-19 patients. Given our interest in the synthesis and pharmacological evaluation of selenorganic derivatives with this review, we aimed to collect all the papers focused on the biological evaluation of ebselen and its close analogues, covering the timeline between 2016 and most of 2021. Our analysis evidences that, even if it lacks specificity when tested in vitro, being able to bind to every reactive cysteine, it proved to be always well tolerated in vivo, exerting no sign of toxicity whatever the administered doses. Besides, looking at the literature, we realized that no review article dealing with the synthetic approaches for the construction of the benzo[d][1,2]-selenazol-3(2H)-one scaffold is available; thus, a section of the present review article is completely devoted to this specific topic.
\end{abstract}

Keywords: ebselen; selenorganic compounds; antiviral; bipolar disorders; hearing loss; selenium chemistry

\section{Introduction}

2-Phenylbenzo[d][1,2]-selenazol-3(2H)-one (compound 1, Figure 1), known as SPI1005, DR3305, PZ-51 or ebselen, was synthesized the very first time by Lesser and Weiss in 1924 [1] in the context of a general organic chemistry paper. Exactly 60 years later, Helmuth Sies tested ebselen for its ability to mimic the antioxidant activity of the glutathione peroxidase (GPx) enzyme [2,3], which was recognized as a selenoenzyme few years before [4,5], paving the way for a completely new branch of investigation, the search for strategies and molecules able to cope with oxidative stress [6].

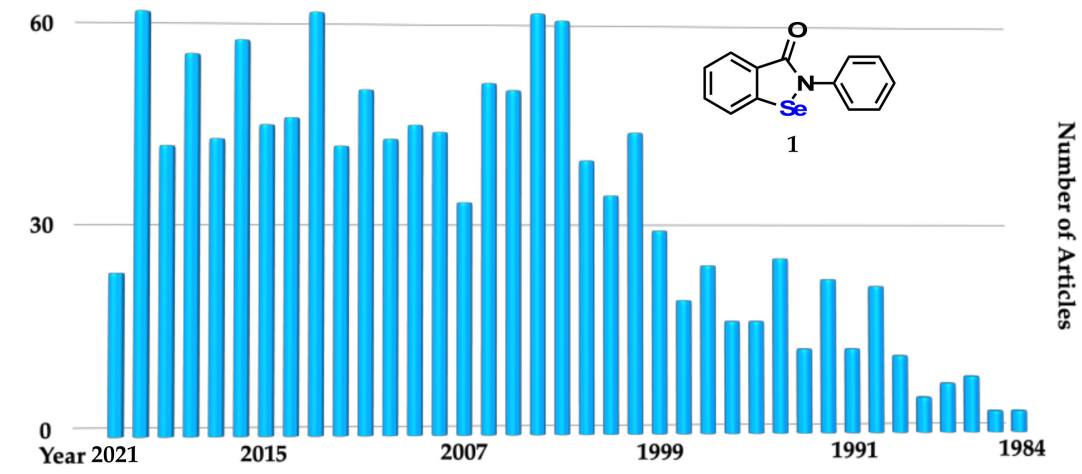

Figure 1. Number of articles on ebselen (1) from 1984. 
Since 1984, the research focused on ebselen spread incredibly with more that 1000 papers exponentially published. In Figure 1, a chart reports the number of articles plotted with respect to years. It was drawn by searching the term "ebselen" in PubMed.

Of course, this selection is devoid of the organic chemistry-oriented papers, which are excluded in PubMed.

Ebselen was included in several clinical trials (see [7] for a list updated to 2017) both in US and Asia, but until now, no concrete perspective of clinical application is visible. Since 2020, due to it being highly active in inhibiting the SARS-CoV-2 main protease (see below), it has been under evaluation in a phase 2 study for its ability to combat SARS-CoV-2 infection in moderate as well as severely affected COVID-19 patients (https:/ / clinicaltrials.gov/ct2 / show /NCT04484025; https:// clinicaltrials.gov/ct2/show/NCT04483973, accessed on 11 June 2021).

In its long history, several biological activities were claimed for ebselen and several review articles $[8,9]$ were published, some even recently $[10,11]$. One is particularly interesting because it places the selenorganic compound in the context of the SARS-CoV-2 treatment [12].

In this review we aim to collect and detail all the synthetic approaches reported for the preparation of such a valuable compound and its analogues; in addition, the results of their pharmacological evaluation, published after 2016, will be cited. Even if ebselen is known as an anti-inflammatory compound, the reader will not find a section entirely devoted to such property. The reason behind this choice is that no paper has yet been published precisely claiming such an activity; most probably because the anti-inflammatory property is so general that it is sometime masked or comprised in other, listed, pharmacological properties.

\section{Synthetic Approaches to Ebselen and Benzisoselenazolones}

As mentioned, ebselen was first prepared almost one hundred years ago by Lesser and Weiss even if, according to CAS SciFinder, the first report of benzisolenazolones synthesis can be traced back only to the 1980s $[13,14]$, when it was built by reacting the dichloride 5, plausibly prepared starting from the 2,2'-diselanediyldibenzoic acid (DSBA, 4), with aniline. DSBA is another key intermediate for the synthesis of organoselenium compounds [15,16], endowed with notable biological properties [17]. Gütschow et al. adopted such a strategy to obtain fluorescent coumarin derivatives [18] while Pietka-Ottlik prepared benzisolenenazolones endowed with antimicrobial activity [19-22]. Similarly, Li et al. prepared a series of cholinesterase inhibitors by using anthranilic acid derivatives, proving the versatility of the synthetic protocol [23]. The reaction works also with terpenyl amines, giving chiral ebselen analogues [24] (Table 1, Method 1). Engman in 1989 prepared the dianion 8 from $\mathrm{N}$-phenylbenzamide 7 through ortho lithiation with nBuLi. Elemental selenium then inserts into the C-Li bond, affording the lithium selenide $\mathbf{9}$, which is finally cyclized to ebselen using $\mathrm{CuBr}_{2}$, probably through the formation of the selenylbromide 10 [25]. This synthetic path was lately pursued by Silks to prepare the ${ }^{77}$ Se labeled version of ebselen [26] and recently adopted by Hsu for the preparation of a small benzisoselenazolones library, then assayed as radical scavengers [27] (Table 1, Method 2). The direct conversion of dianion 8 into 1 through the treatment with the electrophilic $\mathrm{SeCl}_{2}$ was demonstrated by Singh in 2005 (Scheme 1) [28] (Table 1, Method 3). 


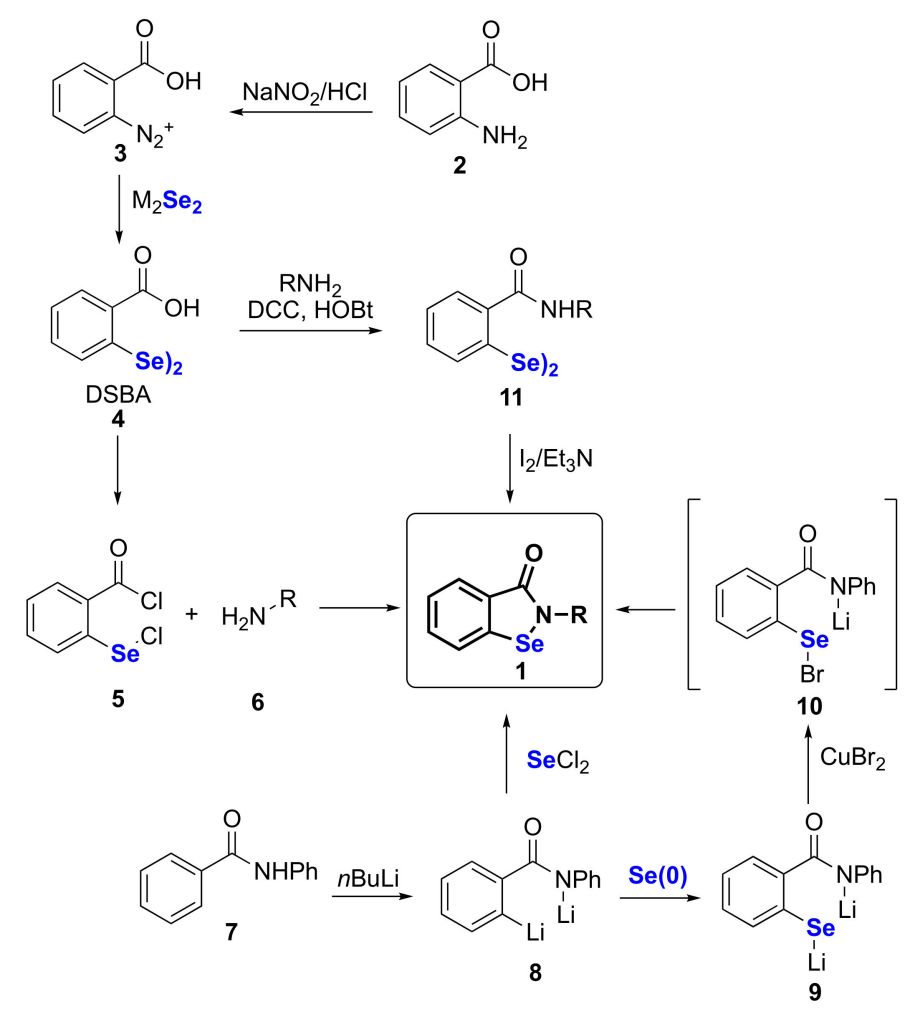

Scheme 1. Synthetic approaches to 1, part one.

The mixed anhydride strategy permitted us to convert DSBA into a set of diselenobisbenzamides $\mathbf{1 1}$ endowed with anti-HIV activity [29] due to their ability to inhibit the key viral protein NCp7 [30,31]. Compounds 11 were straight away cyclized into their ebselen-like analogues by the reaction with molecular iodine under basic activation [32] Thionyl chloride, sulfuryl chloride or bromine are able to do the same job, as demonstrated by Christiaens, even if with longer reaction time [33] (Table 1, Method 4).

Table 1. Synthetic procedures for ebselen $\mathbf{1}$ and its derivatives.

\begin{tabular}{ccccc}
\hline Method & $\begin{array}{c}\text { Starting } \\
\text { Compound }\end{array}$ & $\begin{array}{c}\text { Number of } \\
\text { Steps }\end{array}$ & Yield (\%) & Ref \\
\hline 1 & $\mathbf{2}$ & 4 & $16-67$ & {$[18-24]$} \\
\hline 2 & $\mathbf{7}$ & 3 & 63 & {$[25-27]$} \\
\hline 3 & $\mathbf{7}$ & 2 & 40 & {$[28]$} \\
\hline 4 & $\mathbf{2}$ & 4 & 60 & {$[15,16,32,33]$} \\
\hline 5 & $\mathbf{1 3}$ & 1 & 85 & {$[34]$} \\
\hline 6 & $\mathbf{1 2}$ & 2 & 53 & {$[35]$} \\
\hline 7 & $\mathbf{1 5}$ & 1 & $47-96$ & {$[36,37]$} \\
\hline 8 & $\mathbf{1 5}$ & 1 & $35-88$ & {$[38]$} \\
\hline 9 & $\mathbf{1 5}$ & 1 & $44-91$ & {$[40,41]$} \\
\hline 10 & $\mathbf{1 5}$ & 1 & $59-98$ & {$[42]$} \\
\hline 11 & $\mathbf{1 6}$ & 3 & 76 &
\end{tabular}

In Scheme 2, the synthetic methodologies starting from ortho-bromo-benzamides are reported. In particular, the treatment of $\mathbf{1 3}$ with lithium diselenide in THF at reflux did not 
afford the expected diselenides but the ebselen analogue, instead [34] (Table 1, Method 5). Very recently, Pal Sing and Engman prepared ortho nitro benzisolenazolones by the bromineinduced cyclization of 14, in turn obtained by the aromatic nucleophilic substitution of $\mathbf{1 2}$ with sodium nButyl selenide [35] (Table 1, Method 6).

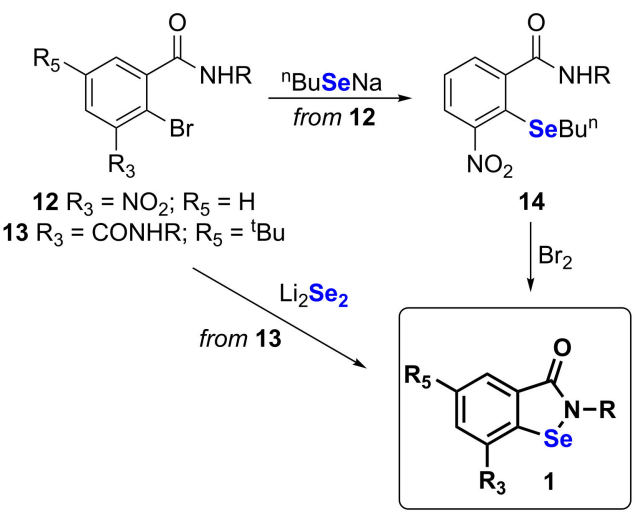

Scheme 2. Synthetic approaches to 1, part two.

Ortho-iodo-benzamides 15 were used as starting material for a number of approaches summarized in Scheme 3. A copper catalyzed approach was reported in 2010 by Kumar and coworkers, who used elemental selenium as selenium sources through what it is thought to be a double selenium insertion, the first one into the copper nitrogen complex and the second in the carbon iodide bond [36,37] (Table 1, Method 7). The same authors later investigated the potassium tert-butoxide-promoted direct organication of elemental selenium [38] (Table 1, Method 8). Stoichiometric amounts of copper iodide were necessary for the construction of the ebselen core in the study published by Sucheck and coworkers, who employed potassium selenocyanate as a selenium source. Interestingly the reaction works well under thermal and photo activation; in the latter case, phenanthroline is not required [39] (Table 1, Method 9). Lithium diselenide in polar solvents is the selenium source in the protocol invented by Scianowski for the construction of diversely $\mathrm{N}$-alkyl, $\mathrm{N}$-aryl functionalized derivatives [40,41] (Table 1, Method 10).

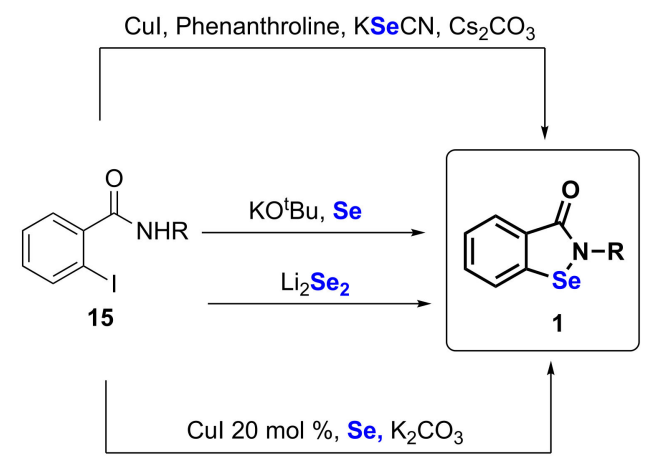

Scheme 3. Synthetic approaches to 1, part three.

Schiesser published the sole approach based on radical chemistry. In particular, the benzyl selenide 16 obtained by treatment of 8 with benzylbromide (not shown), was initially converted into the corresponding iminyl chloride 17 by the reaction with phosgene. Compound 17 was not isolated but reacted with the sodium salt of $\mathrm{N}$-hydroxypyridine-2-thione 18, leading to the pyridine-2-thioneoxycarbonyl imidate ester 19 , which readily underwent photolysis and radical ring closing reaction to afford ebselen (Scheme 4) [42] (Table 1, Method 11). Recently, a review article by some of us gathered the synthetic efforts needed for the preparation of not just ebselen-like structures but also compounds bearing different Se-containing functionalities [43]. 


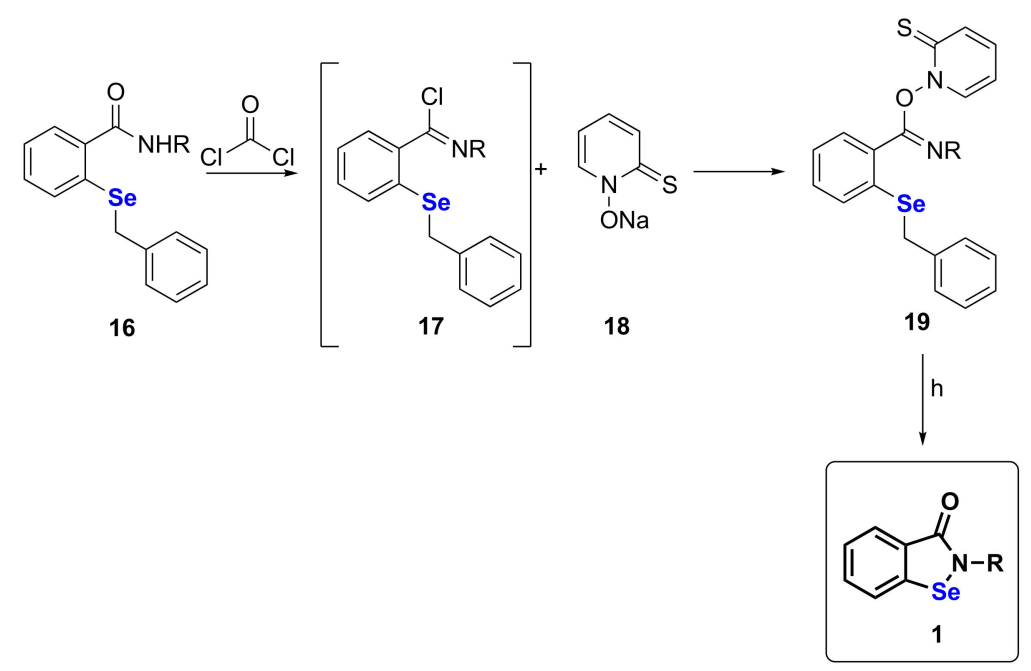

Scheme 4. Synthetic approaches to 1, part four.

In Table 1, a summary of all of the synthetic procedures listed in this section is presented in order to help readers in recognizing the strategy more suited to their needs.

A useful tool to recognize ebselen, as well as the other selenorganic compounds, is ${ }^{77}$ Se NMR spectroscopy. Benzisoselenazolones display a characteristic chemical shift in a range of 900-960 ppm, depending on the used solvent [44].

\section{Antimicrobial Activities}

Several antimicrobial activities were reported for ebselen. Here they will be grouped as follows: antiviral, with particular emphasis on the anti-SARS-CoV-2 activity; antibacterial, effective against anti-mycobacterium tuberculosis; antifungal; and effective against other pathogenic microorganisms. Where reported, ebselen analogues will be detailed underlining the structural determinants that endow the molecules with a better or worse pharmacological profile.

\subsection{Antiviral}

\subsubsection{Anti-Sars-CoV-2}

In 2019, a tremendous viral infection started in China and spread all over the world, revolutionizing our everyday life. The virus was identified as a coronavirus of zoonotic origin, named severe acute respiratory syndrome coronavirus 2 (SARS-CoV-2), which is recognized as the etiological agent responsible for the 2019-2021 viral pneumonia named COVID-19 [45]. With their pivotal paper, Yang and coworkers solved the crystal structure of the key viral enzyme main protease $\left(\mathrm{M}^{\mathrm{pro}}\right)$ in complex with the peptidomimetic inhibitor N3. In the frame of a drug repurposing approach, they tested the so-called "clinical collection", a library of compounds with a history of clinical trials, identifying ebselen as the most potent $\mathrm{M}^{\text {pro }}$ inhibitor with an $\mathrm{IC}_{50}$ of $0.67 \mu \mathrm{M}$. Interestingly, ebselen covalently inhibits the enzyme, being nucleophilically attached by Cys145 within the enzyme active site. The selenylsulfide thus formed is stable enough to permanently inhibit enzymatic activity, resulting in viral inhibition, as demonstrated also in a cellular model of viral replication where ebselen showed an $\mathrm{EC}_{50}$ of $4.67 \mu \mathrm{M}$ [46]. This discovery made the repurposing of ebselen for SARS-CoV-2 treatment a reasonable option, so much so that it entered a phase II clinical trial [47].

Interestingly, the reliability of ebselen as a clinically exploitable $\mathrm{M}^{\text {pro }}$ inhibitor was questioned by Wang et al., who investigated the specificity of the covalent $M^{\text {pro inhibitors }}$ known at that time, demonstrating that the inhibition is fully reversible by the addition of reducing agents such as dithiotreithiol or GSH [48]. 
The Mpro binding capabilities of ebselen were thoroughly investigated computationally, suggesting the possibility to exploit the benzisoselenazolone core not only as an active site binder but also as an allosteric modulator [49]. Very recently the studies regarding the interaction between ebselen and Sars-CoV-2 proteases were extended to the putative ebselen metabolites [50].

Ebselen was later found to inhibit the Zn-containing non-structural proteins (Nsp) 13 and 14. Nsp13, which is an helicasetriphosphatase pivotal for the capping of nascent viral mRNAs, is inhibited with an $\mathrm{IC}_{50}$ of $292 \mathrm{nM}$, while the exoribonuclease activity of nsp14 is blocked with an $\mathrm{IC}_{50}$ potency of $3.18 \mu \mathrm{M}$. The same paper demonstrated that the compound displays synergism with the newly approved anti-SARS-CoV-2 drug Remdesivir [51].

Inspired by these results, several research groups engaged in drug discovery campaigns; even if some preprints are reported, only the peer reviews papers will be detailed. Weglarz-Tomczak et al. reported a series of ebselen-like structures able to inhibit not only $M^{\text {pro }}$, but also the other pivotal protease, a papain-like protease from SARS-CoV-2 with comparable potencies, in the high micromolar range [52]. Yang et al. prepared a series of ebselen and ebsulfur (compound 23, Figure 2) analogues variously functionalized at the nitrogen atom with aryl, alkyl, benzyl and heteroaryl substituent identifying compounds endowed with a better $M^{\text {pro }}$ activity when compared to the native lead compound; interestingly, not only ebselen but also 23 proved to covalently bind $M^{\text {pro }}$ [53]. It is worth mentioning that ebselen-like structures are always more potent when compared to their sulfur analogues.
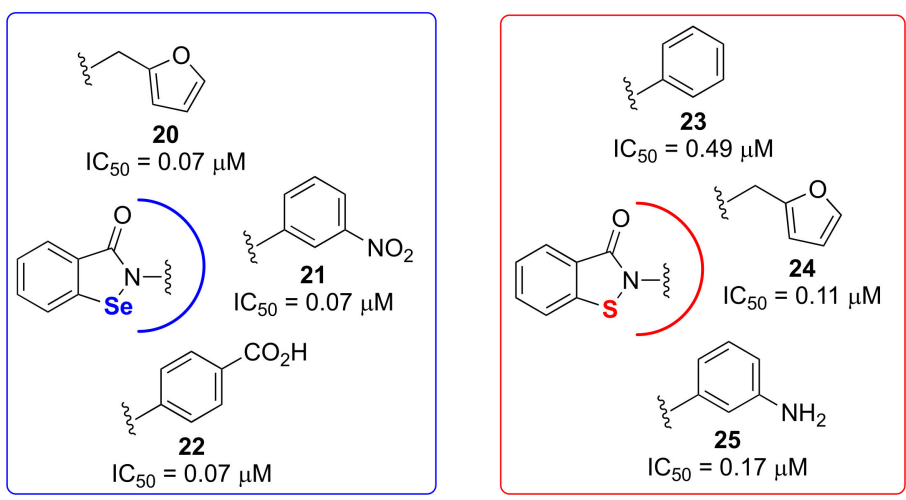

Figure 2. Ebselen and ebsulfur analogues endowed with anti-Mpro activity.

At the time the present review article was almost complete, a very important paper was published by Yang and coworkers who, in an attempt to obtain co-crystal structures between ebselen, its analogues and $M^{\text {pro }}$, found that after protein/small molecule incubation only the selenium atom is present in the enzyme active site, suggesting the mechanism summarized in Scheme 5. In particular, once the selenenyl sulfide intermediate is formed, it reacts through a SNAr-like mechanism with water, leading to the formation of 2-hydroxy-N-phenylbenzamide and the selenenylated Cys145 [54].

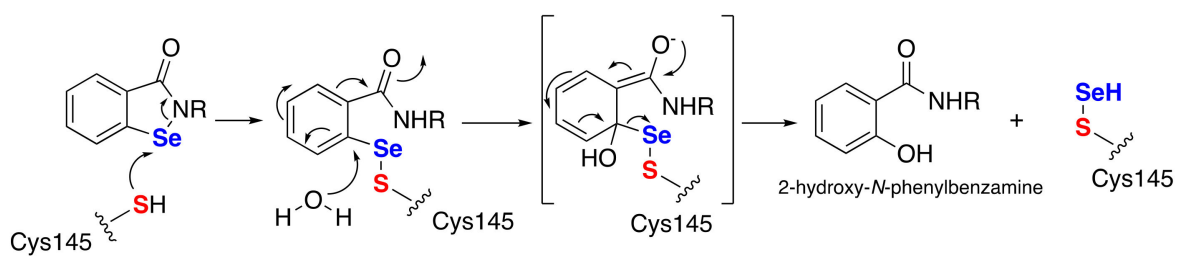

Scheme 5. Selenenylation of Mpro by ebselen-like compounds.

\subsubsection{Anti-HIV}

Despite remarkable progress in treating the human immunodeficiency virus (HIV) the causative agents of the acquired immunodeficiency syndrome are still a serious treat 
worldwide and much needs to be done to achieve its eradication [55]. In the past few years ebselen was reported as a valuable anti-HIV compound because of its multiple activities. It was indeed capable of inhibiting the HIV capsid protein dimerization with activity in the low nanomolar range, by covalently linking at Cys198 and Cys218 of the capsid C-terminal domain, as proved by NMR analysis and electrospray ionization mass spectrometry. When tested in a cellular context, ebselen presented antiviral properties in single and multiple rounds of infection in permissive cell lines as well as in primary peripheral blood mononuclear cells [56].

Later on, Luo et al. proposed ebselen as an indirect integrase inhibitor thanks to its ability to bind to lens epithelium-derived growth factor (LEDGF/p75), a cellular factor hijacked by the HIV-1 virus to allow itself a proper integration process. In this case, the interaction is also thought to be covalent, even if no direct proof was given [57].

\subsubsection{Anti-Influenza, Zika and Other Viruses}

Influenza viruses (flu), are important pathogens responsible for yearly seasonal epidemics and more extensive global pandemics. Indeed, pandemic outbreaks could occur in the case that highly virulent and pathogenic viral strains, deriving from antigenic shift, emerge. Such viral infections are a common cause of acute exacerbations of chronic obstructive pulmonary disease, which is among the major leading causes of death worldwide. This scenario becomes worse after exposure to cigarette smoke, which increases the oxidative stress within the respiratory tract and disrupts the resolution of influenza infection in vivo [58]. Due to its ability to reduce lung inflammation triggered by several stimuli $[59,60]$ and being the prototypical antioxidant, ebselen was tested in an animal model of chronic obstructive pulmonary disease in which both the influenza virus infection and the damage triggered by cigarettes smoke were simulated. It was administered orally and lowered viral titers, when compared with the control group, by reducing viral replication at the very early stage of infection; in addition it reduced oxidative stress and the expression of pro-inflammatory mediators in the lung [61].

Interestingly, very recently ebselen proved to reduce the endothelial disfunction induced by the smoke from cigarettes in vivo [62].

Zika virus (ZIKV) belongs to the flaviviridae family, and is a single-stranded RNA virus that recently created a public health emergency of international concern [63]. Even if its infection has been associated with low cases of fatality, it causes microcephaly in infants and Guillain-Barre syndrome. To date there is no viable or approved treatment, thus the prevention of ZIKV transmission is the sole strategy for disease control and management [64]. Even if the ZIKV transmission prevalently requires an intermediate mosquito (Aedes) host, it was proven that sexual transmission can be an additional and even more dangerous route. Such viral infection creates testicular oxidative stress and proinflammatory response, either impairing the male reproductive capabilities or improving the transmissibility of the virus itself [65]. In 2018, Lin et al. proposed the use of ebselen as a possible therapeutic intervention to alleviate the testicular pathogenesis and prevent the sexual transmission of ZIKV. The selenorganic compound displayed a poor effect on ZIKV replication in culture cells but when administered intraperitoneally at $10 \mathrm{mg} / \mathrm{Kg}$ dose it was able to prevent ZIKV sexual transmission and improved testicular oxidative stress by altering the cytokine profile of treated mice [66].

In 2017, in the frame of a wider study, ebselen together with two of its close analogues were prepared and tested against human herpes virus type 1 (HHV-1), encephalomyocarditis virus (EMCV) and vesicular stomatitis virus (VSV), replicating in the human cell line A549. With the exception of VSV, ebselen and analogues displayed promising activity in terms of minimum inhibitory concentration (MIC), which was in the range of $\mu \mathrm{g} / \mathrm{mL}$ [67]. 


\subsection{Antibacterial}

\subsubsection{Against Pathogenetic Gram-Positive Bacteria}

Some Gram-positive bacteria, such as Staphylococcus aureus, Bacillus anthracis, Clostridium difficile, Enterococcus faecium and Enterococcus faecalis, are pathogenic microorganisms able to cause serious diseases upon infection. B. anthracis causes anthrax, which is associated with a very high mortality rate, and it is perfectly shaped from a bioterrorist point of view. Notably, problems with methicillin-resistant (MRSA) and multidrug-resistant (MDRSA) S. aureus are becoming more and more common; thus the development of new antibacterial agents endowed with a mechanism of action different from that of the clinically used drugs is an urgent need. The thioredoxin system was selected as a target by Holmgren and coworkers in their drug discovery campaign meant to discover agents capable of inhibiting the growth of $B$. anthracis and/or MRSA. Thirteen derivatives were prepared, among them the 4-chloro-pyridin-2-yl-containing compound $\mathbf{2 6}$ and the dimer ethaselen $\mathbf{2 7}$ are worth mentioning (Figure 3). They displayed a higher potency in inhibiting thioredoxin reductase (TR) when compared to ebselen and showed a potent MIC against both S. aureus and B. anthracis [68].

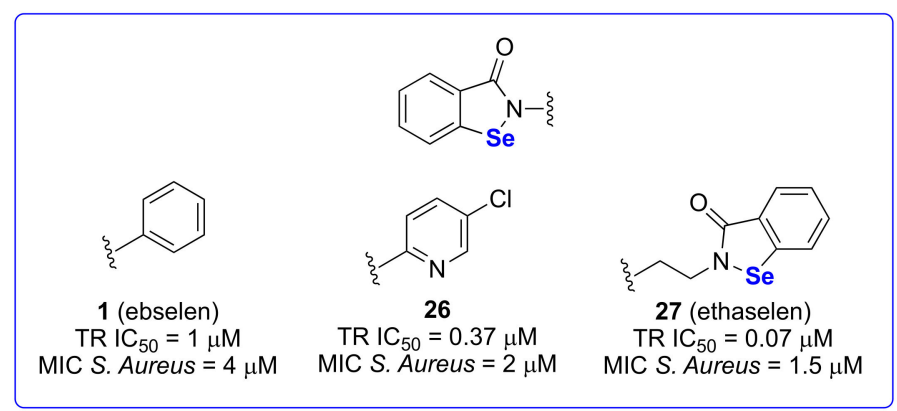

Figure 3. Antibacterial TR inhibitors.

Very recently, ebselen was proved not only to inhibit $S$. aureus TR but also to sensitize the enzyme to curcumin, improving its activity to block the enzyme. In the frame of the same investigation, ebselen was tested topically in a rat model of staphylococcal skin wound infection, proving to have high therapeutic efficacy against MDRSA [69].

Seleem et al. proved that ebselen was unable to select $S$. aureus-resistant variants even after 14 consecutive passages [70]. Pietka-Ottlik prepared ebselen, a series of its analogues and a small library of diselenides, then tested for their ability to inhibit S.aureus and other Gram-positive pathogenic bacteria, identifying some suitable preclinical candidates [67].

Pressure ulcers (PUs) are a serious threat worldwide, affecting people with limited mobility, including those who are obese, and their bacterial infection surely represents a leading cause of hospital admissions. S. aureus is among the most dangerous bacterial species that often infect PUs. For this reason, ebselen was tested topically for its ability to reduce the burden of MRSA in infected PUs both in obese and diabetic mice but, disappointingly, it proved to be ineffective [71]. The same authors proposed ebselen as a valuable agent to decolonize vancomycin-resistant enterococci (VRE) from the gastrointestinal tract (GIT) of high-risk patients. Among the most problematic enterococci, Enterococcus faecium and Enterococcus faecalis are listed as high-priority pathogens by the World Health Organization (WHO). Within their study, the antibacterial activity of ebselen, together with clinically used antibacterial drugs, was evaluated against several strains of enterococci from humans and animals, revealing that the selenorganic compound was found to have antibacterial activity against all the tested isolates, whereas the control compound lacked activity against some strains. In the resistance selection test, ebselen was evaluated via a multi-step resistance selection experiment against vancomycin-resistant $E$. faecium, with the MIC unchanged after 14 passages. In contrast, resistance to gentamicin, which was tested in parallel, emerged rapidly. The antibiofilm capabilities were also determined, 
and it proved to be superior when compared to all the other tested drugs in eradicating preformed VRE biofilms [70]. This finding is really important; indeed, very few examples of selenorganic compounds endowed with such an activity are reported in literature [72].

Ebselen was then tested in vivo in mice colonized with VRE. It was administered orally at $10 \mathrm{mg} / \mathrm{Kg}$ dose and it was able to significantly reduce the bacterial burden in fecal samples after just three days of treatment [70].

Clostridium difficile infection (CDI) is directly linked to thousands of deaths per year in both the US and in Europe [73]. CDI is facilitated by a wrong use of antibiotics, which induces dysbiosis in the commensal microbial communities of the GIT. A number of commercially available antibacterial drugs taken for unrelated conditions have been shown to disrupt the GIT microbiome in humans, causing a state that is permissive for CDI [74]. Ebselen was reported to act as valuable anti-CDI agent in vivo by covalently inhibiting large clostridial toxins ((toxins A (TcdA) and B (TcdB)) [75]. Besides, the selenorganic compound proved not only to block the onset of CDI but also to reduce the recurrence rates of CDI, decreasing at the same time colitis in a hamster model [76].

\subsubsection{Against Pathogenetic Gram-Negative Bacteria}

The increasing occurrence of MDR Gram-negative bacteria has become a tremendous health threat worldwide. Klebsiella pneumoniae, Pseudomonas aeruginosa, Acinetobacter baumannii and Escherichia coli are just a selection of what the WHO defines as "priority pathogens" [77]. The main difference between Gram-positive and Gram-negative bacteria is that the latter have two cellular membranes, with the outer one being impermeable to most small molecules. This natural barrier poses a tremendous challenge to the medicinal chemistry community that tries to develop broad-spectrum antibacterial agents [78]. Among the strategies to allow a better penetration into the periplasm, the increment of the hydrophilicity is among the most pursued. With this in mind, Yang and Chen prepared a series of ebselen analogues bearing aliphatic and polar functionality at the amidic nitrogen (representative compounds 28 and 29, Figure 4) [79].

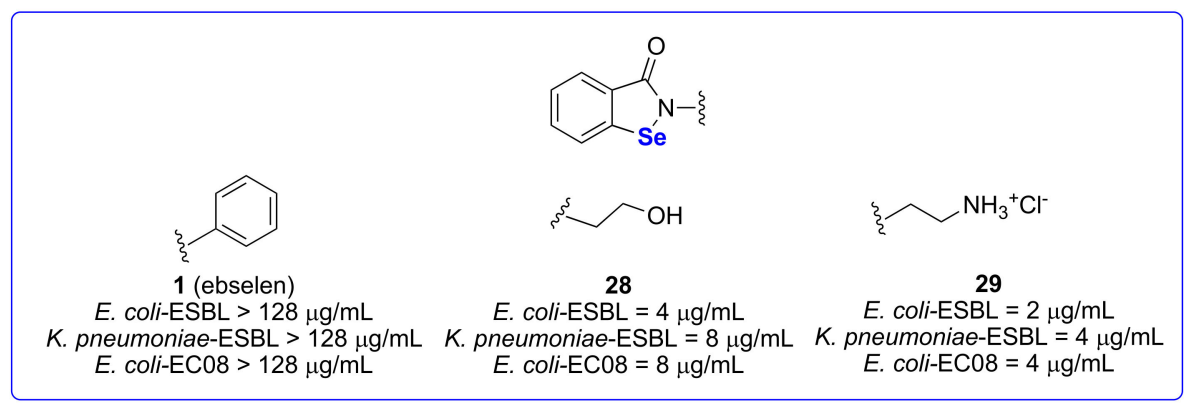

Figure 4. Hydrophilic ebselen analogues endowed with anti-Gram-negative bacteria properties.

Compounds 28 and 29, being way more hydrophilic than ebselen, readily accumulated into the Gram-negative pathogenic bacteria, most probably by passing through the porins and exerted a powerful bactericidal activity with potency in the low micromolar range [79]. The K. pneumonia tested in this study expresses the so-called New Delhi metallo- $\beta$-lactamase (NDM-1), a kind of metallo- $\beta$-lactamases capable of destroying $\beta$-lactam-containing antibiotics by attacking the carbonyl group of the $\beta$-lactam through a zinc-bound hydroxyl ion. Such an enzyme was the target of a drug discovery process very recently carried out by Chan et al., who employed the benzisoselenazolone and its sulfur analogue benzisothiazole cores as templates for the synthesis of potent NDM-1 blockers [80-82].

In 2017, Holmgren et al. reported a synergistic activity between compound $\mathbf{1}$ and silver ions in inhibiting both E. coli thioredoxin and TR, highlighting that TR could be a suitable target not only in the anti-Gram-positive bacteria research field. The combination of the selenorganic compound and the metal increased the reactive oxygen species (ROS) content, lowering the MIC of the metal and making it more selectively toxic to bacteria 
over mammalian cells [83]. In 2020, the very same concept was implemented by Zou and colleagues who, using a clinically isolated uropathogenic E. coli strain, proved the efficiency of an ebselen/silver ion combination in reducing acute cystitis infections in a mouse model [84].

P. aeruginosa is an opportunistic pathogen that causes acute as well as chronic infections in immunodeficient people, such as those under antineoplastic chemotherapy or AIDS patients [85]. Importantly, P. aeruginosa is found in the airways of cystic fibrosis (CF) patients, whose mucociliary clearance is hampered, making the airways more susceptible to microbe infections [86]. In the context of CF, P. aeruginosa is able to develop a particular resistance mechanism. It starts to produce alginate by overexpressing alginate biosynthesis proteins, building a physical shield and making it resistant to antibiotics and, at the same time, further occluding and impairing lung function [87]. Very recently, Lee et al. discovered ebselen-like compounds and ebselen selenoxide (compound 30, Figure 5) as valuable anti-Pseudomonas agents capable of inhibiting alginate production. Interestingly the selenoxide derivative showed a sixfold higher potency, if compared to 1 [88].

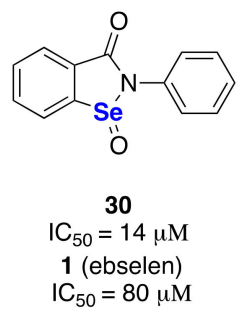

Figure 5. Structure of $\mathrm{IC}_{50}$ for alginate inhibition.

\subsubsection{Against Mycobacterium Tuberculosis}

Tuberculosis is an old infectious disease caused by Mycobacterium tuberculosis (Mbt), a kind of microorganism that represents the transition state between fungi and bacteria, falling into both the Gram-positive and negative clusters. The standard of care relies on two lines of intervention which differ according to the tolerability of the drug treatment but, in both cases, last for months. Most of the anti-Mbt first-line drugs are poorly tolerated and as a result the adherence sometimes fails, making the selection of multidrug- and total drug-resistant strains a common outcome [89]. For this reason, the development of newer anti-Mbt drugs is highly demanded. In 2013, ebselen was discovered as a potent inhibitor of the three essential homologous $M t b$ proteins of the antigen 85 complex (Ag85A, Ag85B, andAg85C) and having a MIC of $20 \mu \mathrm{g} / \mathrm{mL}$ [90]. Starting from this milestone, a series of ebselen analogues was designed and synthesized [39] and in a recent report, two highly promising derivatives (compound 31 bearing a 4-azido-phenyl moiety and 32 bearing an adamantly functionality, Figure 6) were co-crystallized in the presence of $\mathrm{M} t b \mathrm{Ag} 85 \mathrm{C}$, yielding two X-ray crystal structures of 2.01 and $1.30 \AA$ resolution, that surely represent a valuable tool for the design of more potent analogues. As expected, both structures displayed the anticipated covalent modification of the noncatalytic Cys209 residue, forming a selenenylsulfide bond [91].

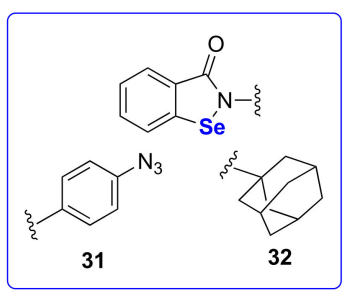

Figure 6. Structures of $M t b$ Ag85C binders.

The L,D-transpeptidase of $M b t$ is considered an innovative target, which is not currently reached by the used drugs, for the development of next-generation anti-mycobacterium 
drugs. It was the protein selected Brem et al., who discovered ebselen by screening a library of cysteine-reactive reagents. The selenorganic compound binds to Cys354, proving that such a protein could be targeted not just with $\beta$-lactamines [92].

\subsubsection{Against Pathogenetic Fungi}

Among the most widespread infectious diseases globally, the ones caused by fungi are worth mentioning. Almost one billion cases of either superficial or cutaneous mycoses are recorded around the world per year and they account for 1.6 million global deaths [93]. In this scenario, the search for agents able to prevent or subvert mycoses is a global priority. Diphenyl diselenide and ebselen are among the most studied selenorganic compounds as antifungal agents and recently a review article focused on the medical aspects has been published [11], for this reason, herein the attention will be devoted to medicinal chemistry-oriented reports focused on ebselen and analogues even if examples of selenorganic compounds endowed with antifungal properties were reported $[67,94]$.

In 2017, compound 1 was assayed against 15 strains of Candida albicans, 2 of C. glabrata, 2 of C. tropicalis, C. parapsilosis and 9 of Cryptococcus neoformans in vitro, and subsequently it was tested in vivo in a Caenorhabditis elegans animal model. Ebselen showed MICs ranging from 0.5 to $2 \mu \mathrm{g} / \mathrm{mL}$ and it proved to be better than the clinically used fluconazole, flucytosine and amphotericin in reducing Candida and Cryptococcus fungal load in vivo. From a mechanism of action point of view, ebselen was able to deplete fungal cells of glutathione (GSH), triggering a ROS storm that eventually kills the microbe [95].

The same year, Billack et al. reported a series of ebselen analogues as inhibitors of the plasma membrane $\mathrm{H}^{+}$-ATPase proton pump (Pma1p), which is considered an intriguing target since it is critical to fungal survival. Beside ebselen, which showed an interesting inhibitory activity toward the pump $\left(\mathrm{IC}_{50}=4 \mu \mathrm{M}\right)$ and the growth of fluconazole-resistant C. albicans strain, ebsulfur (compound 23, Figure 2) and the aza-compound 33 (Figure 7) also showed promise [96]. The same authors recently developed a nanoemulgel-based formulation of ebselen for the treatment of superficial candidiasis, which showed a higher activity when compared with terbinafine even at high concentration [97].

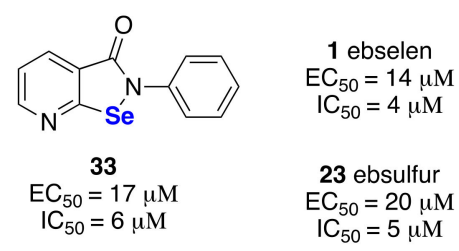

Figure 7. Structure of compound 32 and pharmacological data for compounds 1, 23 and 33.

Candida auris, isolated for the first time in 2009, is now considered an emerging pathogen since, from that time, it quickly spread and has become a growing threat in hospitals around the globe [98]. Unfortunately, antifungal therapy against infections caused by C. auris is ineffective because up to $90 \%$ of isolates are resistant to fluconazole and other azoles. In an attempt to discover suitable agents against this emerging pathogen, Lopez-Ribot et al. reported a drug repurposing approach in which they screened the Prestwick Chemical library, composed of 1200 small molecules with a history of clinical use. From this screening, ebselen emerged as the best-in-class compound with an $\mathrm{IC}_{50}$ of $1.41 \mu \mathrm{M}$. In the frame of the same study, ebselen proved to be effective also against $C$. auris clinical isolates. The selenorganic compounds proved to be able to inhibit biofilm formation where the clinically used echinocandins proved to be inactive [99].

\subsubsection{Against Other Pathogenetic Microorganisms}

African sleeping sickness, caused by the eukaryotic pathogen Trypanosoma brucei, is a serious problem, particularly in sub-Saharan Africa, with no apparent solution since the available treatments are largely ineffective or poorly tolerated [100]. Both Ebselen and its 
sulfur analogue, ebsulfur (compound 23), were reported to exert anti-T. brucei activity by inhibiting its hexokinase 1 (TbHK1), which is a pivotal enzyme for the pathogen energy production chain [101]. Recently, the benzoisoselenazole and thiazole scaffolds were studied through the synthesis of analogues, then assayed for the inhibition of TbHK1 activity and T. brucei growth. The most interesting compounds are reported in Figure 8. Interestingly, the removal of the $\mathrm{N}$-phenyl ring abolishes the anti-TbHK1 activity (compound 34 and 36). Nevertheless, such compounds still have the ability to inhibit the trypanosome cellular growth with micromolar potencies [102].
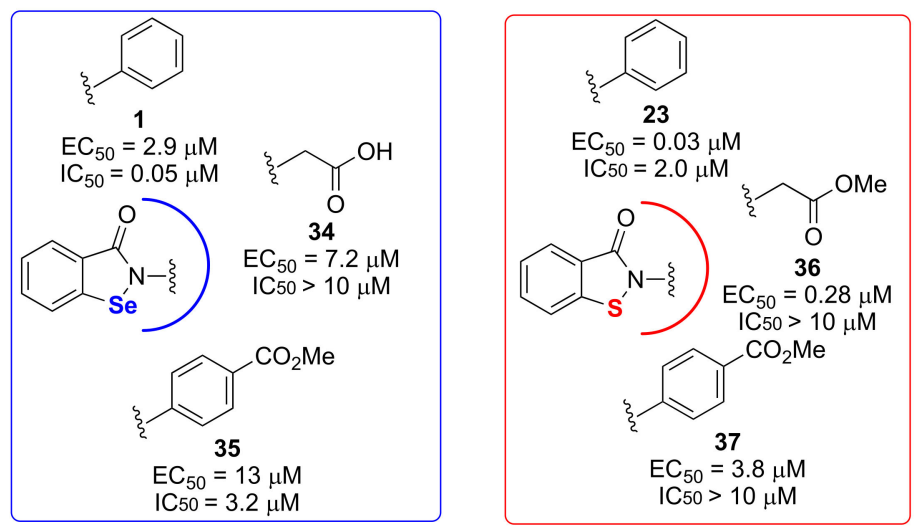

Figure 8. Anti-T. brucei compounds. $\mathrm{EC}_{50}$ is the ability of compounds to inhibit T. brucei growth while $\mathrm{IC}_{50}$ is the enzymatic activity.

Cryptosporidium parasites are the causative agents of severe diarrhea that impedes the growth of children and sometime is associated with premature child death [103]. Unfortunately, nitazoxanide is the only approved drug to treat cryptosporidiosis, but its use is limited to immunocompetent patients, while for immunocompromised ones there are no effective treatments for such a condition. In 2018, by testing the Prestwick Chemical library, ebselen was identified as an inhibitor of the glucose-6-phosphate isomerase of C. paroum (CpGPI). The enzymatic inhibitory activity translated to the ability to inhibit the growth of the parasite in vitro. Interestingly, the selenorganic compound proved to be more selective for the protozoal rather than the human isoform of the same enzyme [104].

Primary amebic meningoencephalitis is a rare and fatal disease of the central nervous system caused by the amoeba Naegleria fowleri. No effective treatments are available and the drug discovery projects are made difficult by the fact that the compounds need to cross the blood-brain barrier (BBB) to be active. Ebselen, and one of its close analogues, being known to cross the $\mathrm{BBB}$, were tested and found active in killing $N$. fowleri trophozoites in vitro with an activity of $6.2 \mu \mathrm{M}$, which was notably lower than the concentration ebselen reaches in plasma, making its actual clinical exploitability valid as a ready-to-use alternative [105].

\section{Antiproliferative Activities}

According to the $\mathrm{WHO}$, cancer is the second leading cause of death globally, with almost 10 million deaths in 2020 [106]. In recent years, efforts have been made to design and synthesize a number of Se-organic molecules in an attempt to develop new strategies for the treatment of neoplastic disorders. In this context, research papers and reviews have been published [107-111].

Among the whole class of selenorganic compounds [112,113], the most promising derivative in the anticancer research field is ethaselen (compound 27, Figure 3), which is under clinical evaluation in TR, overexpressing non-small cell lung cancers [114]. Ebselen and ebsulfur are also proven to interfere with TR [115] and in 2018 their scaffolds were used as a template for the synthesis of novel TR inhibitors. In particular, the N-phenyl ring was replaced with a metallocenyl group, increasing the benzisoselenazolone antiproliferative 
activity tested in MCF-7 cells, a model of breast cancer (Figure 9). Interestingly, the anti-TR activity well correlates with the compound's ability to inhibit MCF-7 growth [116].

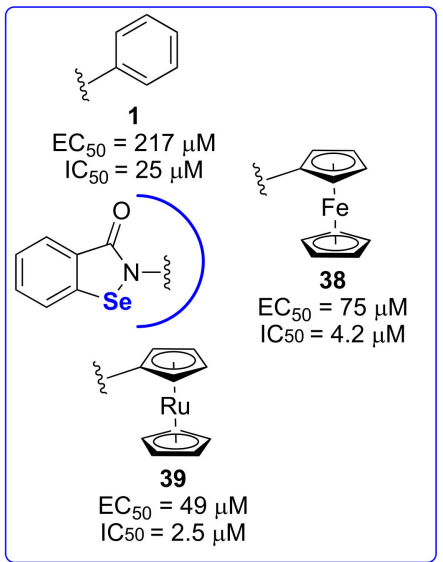

Figure 9. Structure of TR inhibitors. $\mathrm{EC}_{50}$ is the ability of compounds to inhibit MCF-7 growth while $\mathrm{IC}_{50}$ refers to the anti-TR activity.

Beside TR, ebselen is proven to interfere with other targets to exert anti-proliferative activity. As an example, when administered to rat pancreatic tumor AR42J cells, it led to the phosphorylation of crucial components in mitogen-activated protein kinase (MAPK) pathways and oxidative stress at the level of endoplasmic reticulum. The combination of such effects ultimately results in cancer cell death [117].

6-Phosphogluconate dehydrogenase (6PGD) is a key enzyme in the pentose phosphate pathway which is overexpressed in several cancers and linked with enhanced cell growth and drug resistance. Very recently, ebselen was found to inhibit, with nanomolar potency, the activity of 6PGD, even in the context of cellular models of cancer. The enzymatic inhibitory activity translated into the ability to inhibit the growth of 6PGD overexpressing cells. Interestingly, the activity of the selenorganic compound was also evident in a xenograft mouse model [118].

Histone deacetylases (HDACs) are a class of enzymes very important for the synthesis of DNA since they remove acetyl groups from lysine residues of histones, improving the stability of the histones/DNA complex and negatively influencing DNA transcription [119]. Being a key regulator of gene expression, HDACs are a recognized target for the development of anticancer drugs. In humans, HDACs comprise a family of 18 members with different roles in the cells, so the real goal is the discovery of subtype selective HDAC inhibitors. With this in mind, Ma et al. recently reported that ebselen is a pan-HDAC inhibitor while compound 40 (Figure 10) is able to block HDAC6 with low nanomolar potency. Such enzymatic inhibitory activity translates into the ability to inhibit the growth of several models of cancer [120].

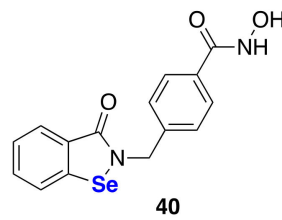

Figure 10. Structure of HDAC6 inhibitor.

Among the medicinal chemistry projects focused on the manipulation of the benzisoselenazolone scaffold, in 2017 Scianowski et al. reported a switchable synthetic procedure to prepare both diselenides as well as ebselen-like structures, the latter were then screened against a panel of cancer cell lines. Worth mentioning are compounds $\mathbf{4 1}$ and $\mathbf{4 2}$ (Figure 11), which exerted a broad antiproliferative activity, being active toward models of breast carci- 
noma (MCF-7), liver cancer (HEPG2 cells), human promyelocytic leukemia (HL60 cells) and prostate cancer (DU145 cells). While compound $\mathbf{4 1}$ showed a fairly selective antiproliferative activity, the methylbutyl-containing compound 42 was also able to exert cytotoxicity when tested in a non-cancerous PNT1A cell line [121,122]. The dynamic of the anti-prostate cancer inhibition of compound $\mathbf{4 2}$ was later studied in detail in a successive report by the same author [123].
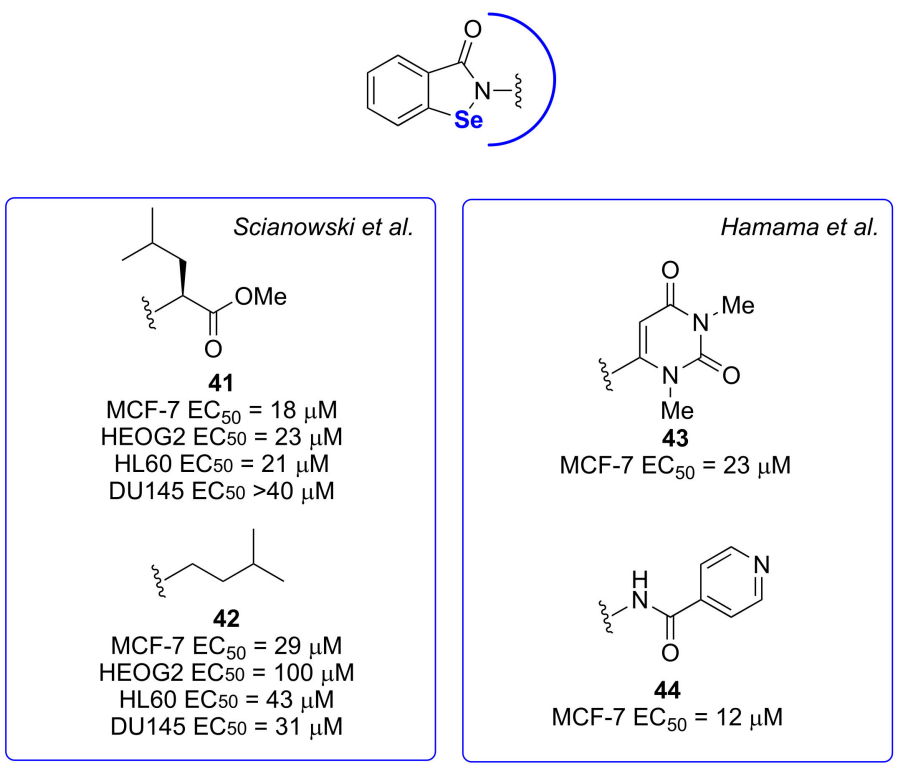

Figure 11. Compounds endowed with antiproliferative activities.

Compounds $\mathbf{4 3}$ and $\mathbf{4 4}$ (Figure 11) were reported the same year by Hamama et al.; also in this case no selectivity was observed, the compounds being endowed with a low micromolar anti-proliferative activity measured in the MCF-7 cell line and in the normal human lung fibroblast cell line (WI-38) [124].

The MCF-7 cell line is a valuable model of breast cancer widely used to assess ebselen's anti-proliferative properties. In this context, it was proven that $25 \mu \mathrm{g}$ of compound $\mathbf{1}$ in combination with $\gamma$-radiation (6 Gy) has a significantly synergistic anti-proliferative effect. Such combination modulates gene expression, and inflammatory cytokines' response, which results in the induction of apoptosis [125].

\section{Anti-Neurodegenerative Disorders}

\subsection{Anti-Alzheimer's Disease}

Alzheimer's disease (AD) is a devastating neurodegenerative disorder which is the leading cause of dementia in Western societies. Currently, the standard of care is purely palliative; indeed, the pharmacological treatments are unable to slow down the damage and destruction of neurons that cause Alzheimer's symptoms and make the disease fatal. Even if the etiology of AD is still unknown, multiple factors are recognized to play a role in its pathogenesis; among these oxidative stress, inflammation, low levels of acetylcholine, $\tau$-protein aggregation and $\beta$-amyloid $(\mathrm{A} \beta)$ deposits are recognized features $[126,127]$.

In 2017, Liu et al. investigated the effects of a compound on AD-associated pathology and cognitive dysfunction using an AD model cell line, primary neurons and an AD mouse model. According to their results, ebselen was able to improve cognitive impairment, reduce the level of the most toxic soluble $A \beta$ oligomers and inhibit $\tau$ hyperphosphorylation [128]. Later, compound 1 was tested against two acetylcholinesterase (AChE) isoforms and, at the same time, in a mouse model of amnesia by Nogueira et al. It was found that ebselen is a potent blocker of the AChE/G4 in vitro and elicits an antiamnesic effect in a scopolamine mouse model at relatively low concentrations [129]. The same research team 
tested ebselen in a streptozocin-induced mouse model of sporadic AD. The compound was administered intraperitoneally at the dosage of $10 \mathrm{mg} / \mathrm{kg}$, proving several positive effects such as the reversal of memory impairment, antioxidant and anti-apoptotic effects that were superimposable to those elicited by the clinically used drug donepezil $[130,131]$.

Since 2013, in light of its antioxidant activity, ebselen was used as a molecular platform for the development of anti-AD agents. It was merged with donepenzil in order to obtain multi-target-directed ligands (MTDL) capable of inhibiting both cholinesterases and oxidative stress simultaneously [132]. The synthesis of MTDL, also known as designed multiple ligands [133], is a new avenue in medicinal chemistry used not only in AD but also in several other research fields [134-136]. Recently, the benzisoselenazolone scaffold was merged with clioquinol, a compound known for its ability to chelate metals and inhibit $\mathrm{A} \beta$ deposits. Among the synthesized compounds, derivative 45 (Figure 12) exhibited the most potent inhibition of $A \beta$ aggregation and excellent antioxidant activity. The compound was able to penetrate the CNS without showing toxicity in vivo [137].

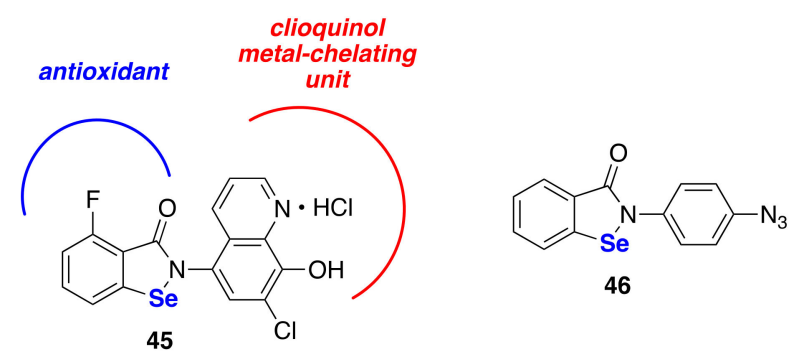

Figure 12. Structure of anti-AD compounds.

Very recently, Sucheck et al. prepared a series of benzisoselenazolone derivatives identifying compounds 20 (Figure 2) and 46 (Figure 12) as promising neuroprotective compounds being able to protect human neuroblastoma SH-SY5Y cells against insult induced by an oxygen-glucose deprivation/reperfusion assay as a model of ischemia. These compounds behaved better than ebselen, taken as reference. Unfortunately, in vivo studies are lacking to definitely assess their actual clinical exploitability [138].

\subsection{Anti-Amyotrophic Lateral Sclerosis}

Amyotrophic lateral sclerosis (ALS) is a neurodegenerative disorder that affects the nervous system, leading to the degeneration of the spinal cord, that results in muscle weakness and atrophy, and respiratory failure. Unfortunately, with no effective cure available, ALS is fatal [139]. Evidence has clearly demonstrated that mutations to the gene encoding for superoxide dismutase-1 (SOD1) are associated with a subset of ALS [140]. The A4V substitution is one of the most severe mutations, causing destabilization and aggregation in ALS patients.

In 2018, Hasnain et al., through a drug repurposing approach, meant to discover "orphan diseases" treatments, found ebselen and ebsulfur (compound 23) as SOD1 binders. They both link to Cys111, promoting the correct SOD1 folding and zinc binding and preventing its premature degradation and aggregation, ultimately hampering its toxicity. In light of this, ebselen can be considered as a valuable alternative to the recently approved drug edavarone [141]. Later, the same research group engaged in a broader study where they prepared a series of benzisoselenazolone and thiazolone analogues, identifying compounds 47-49 (Figure 13) as potent Cys111 modifiers. For each compound, suitable crystal structures were obtained, and this is really important from a de novo drug design perspective [142,143]. 


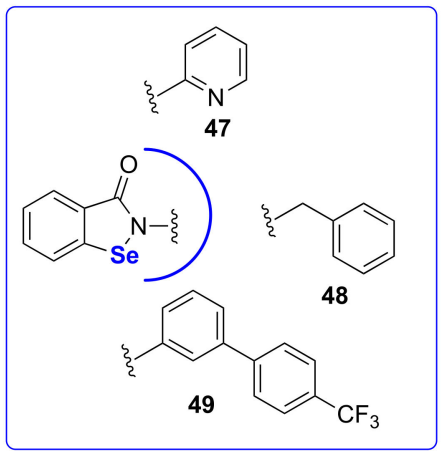

Figure 13. SOD1 Cys111 modifiers.

\section{Anti-Bipolar Disorders}

Bipolar disorder surely represents a serious health threat worldwide, particularly in the developed countries. Lithium carbonate is the only treatment which is able to act as mood stabilizer, controlling both mania and depression while decreasing suicide rates [144]. Unfortunately, the lithium mechanism of action is still unknown even if the so-called Berridge's "inositol depletion" hypothesis delivers a valid mechanistic explanation. It relies on the metal's ability to normalize the signaling in overactive neurons by inhibiting inositol monophosphatase (IMPase) and depleting myo-inositol [145]. With this in mind, the Churchill group proved that ebselen inhibited IMPase and caused a lithium-like effect in mice [146] then, they proved that the compound was able to exert the same effect in humans. In particular, ebselen was tested in a randomized, double-blind, placebo-controlled, crossover design administered orally $(3 \times 200 \mathrm{mg}$ capsules). As assessed by proton nuclear magnetic resonance, it slightly reduced myo-inositol levels in the anterior cingulate cortex, an anatomical region associated with emotional processing and bipolar disorder; in addition, it affected emotional processing in vivo [147]. In a successive investigation, they confirmed the above findings, finding also that the selenorganic compound was able to lower the glutaminase activity, further demonstrating ebselen's viability as a treatment for bipolar disorder $[148,149]$. When challenged with the Cambridge Gambling Task, people receiving ebselen (3600 $\mathrm{mg}$ over $24 \mathrm{~h}$ ) proved to have decreased impulsivity [150], confirming what was initially observed in a rodent model [151]. In different rodent models, compound 1 proved to reduce pilocarpine-mediated neural activation where lithium did the opposite. The ability to lower the muscarinic tone could explain the better tolerability of the selenorganic compound with respect to the metal when administered clinically [152].

The direct interaction between ebselen and IMPase was demonstrated in 2020 by Fenn et al., who solved the $1.47 \AA$ resolution crystal structure of compound 1/IMPase complex, in which a covalent bond links the electrophilic selenium to Cys141 [153].

Another randomized, double-blind, placebo-controlled clinical trial took place between October 2017 and June 2019, where ebselen was administered for 3 weeks at the dose of $600 \mathrm{mg}$ twice a day to patients experiencing mania or hypomania. It proved to be numerically, but not statistically, superior to placebo, especially in those people who concomitantly received valproate treatment [154].

Like lithium carbonate, ebselen decreased $5-\mathrm{HT}_{2 \mathrm{~A}}$ receptor function in in vivo behavioral models and in vitro molecular models, further evidencing its potential role as an antidepressant in the treatment of bipolar disorder [155].

\section{Anti-Hearing Loss/Ototoxicity}

The hearing loss induced by noise is a major determinant of injury and disease in many teenagers and young adults. The reason behind this is the use of personal music players at relatively high volume and exposure to loud sounds, in particular in environments such as bars and clubs [156]. Evidence clearly indicates that GPx1 has a role in maintaining 
normal cochlear functions in mammals; indeed, GPx1 depletion increases vulnerability to noise-induced ear damage [157]. Because of its ability to mimic the activity GPx, ebselen proved to reduce hearing damage in animal models [158-160] even if it was unable to prevent the cochlear damage triggered by 2-hydroxypropyl- $\beta$-cyclodextrin, which however exerts damage by an oxidative stress-independent fashion [161].

Between January 2013 and March 2014, ebselen was assayed in a single-center, randomized, double-blind, placebo-controlled phase 2 trial on 85 healthy adults meant to check its otoprotection capabilities in reducing the temporary threshold shifts (TTS). The outcome of this trial proved that the compound is effective in blocking the TTS at the dose of $400 \mathrm{mg}$ [162].

Among insults leading to hearing loss, aminoglycosides are worth mentioning because of their central role in the antimicrobial treatment in the context of cystic fibrosis $(\mathrm{CF})$ management. Tobramicin, inhaled or injected, is a common drug in CF patients even if its use is associated with cochleotoxicity. Very recently, ebselen was tested in vitro in coadministration with the aminoglycoside, proving to reduce its damage. The in vitro results were confirmed in vivo, in a mouse model of auditory brainstem responses [163].

In 2019, the covalent inhibition of the insulin-degrading enzyme $\left(\mathrm{IC}_{50}=42 \mathrm{nM}\right)$ was suggested as an ancillary mechanism confirming ebselen's anti-hearing-loss capacities [164]. The investigational efforts focused on ebselen in this particular research field were recently collected in a review article by Sound Pharmaceutical [165].

\section{Miscellaneous Activities}

\subsection{In Vivo}

The treatment of myocardial infarction usually relies on coronary reperfusion therapy, which however initiates a chain of events that result in additional cell injury called ischemia-reperfusion injury (IRI) [166]. In 2019, ebselen's ability to attenuate myocardial IRI was assessed in vivo; in addition, it improved cardiac dysfunction, reducing apoptosis seemingly by increasing the expression of Bcl-2 in myocardial cells [167].

In 2016, a study meant to determine ebselen's ability to decrease oxidative stress and improve endothelium-dependent vasodilation in patients with diabetes was carried out. In particular, a single-site, randomized, double-blind, placebo-controlled, crossover trial of 4 weeks in adults with diabetes and increased oxidative stress proved that ebselen was inactive in reducing markers of oxidative stress and arteriolar vascular function [168].

\subsection{In Vitro}

Ebselen was proved to inhibit in vitro a series of enzymes, thus paving the way for different therapeutic applications. Among the most recent examples, glutamate dehydrogenase (GDH) is an important enzyme in mitochondrial glutamate metabolism, which was found to be a potential target for the treatment of brain cancer. In a series of papers, Ruan et al. discovered that compound $\mathbf{1}$ is able to inhibit E. coli as well as human GDH $[169,170]$. Noteworthily, while the bacterial enzyme is inhibited covalently, the human isoform is bound reversibly. The reason behind this contrasting behavior is that the human isoform has an alanine residue in the place of a cysteine, capable of establishing a selenylsulfide bond with the selenorganic compound [171].

Methionine aminopeptidases (MetAPs) are neutral aminopeptidases containing metal ions that catalyze the removal of amino acids from the N-terminus of nascent peptides or proteins. Human MetAP type 2 (MetAP2) is one of the three known methionine aminopeptidases, linked to several types of cancer, which was the target of the drug discovery project by Weglarz-Tomczak et al. Starting with ebselen, a series of benzisoselenazolone and diselenide derivatives was prepared with compounds 48 and 50 bearing benzyl and 2-chloro-4-methyl phenyl fragments, respectively (Figure 14) resulting in the best-in-class being able to inhibit MetAP2 with a higher potency compared with ebselen [172]. 


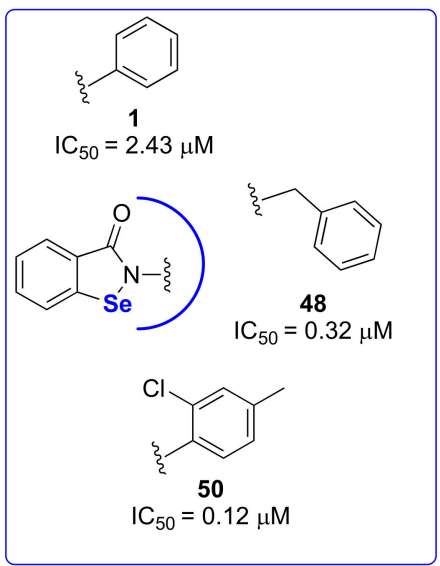

Figure 14. Structures and activity of MetAP2 inhibitors.

\section{Conclusions}

Starting from its synthesis and successive biological evaluation, ebselen can be surely indicated as the most inspiring among the selenorganic compounds. It is currently taken as a reference in several pharmacological investigations even if it is now clear that it acts as what medicinal chemists name as a pan-assay interference compound (PAIN) because of its ability to bind non-selectively to reactive cysteines, being nucleophilically attached by the aminoacidic thiol functionality to the electrophilic selenium. As a proof of this, Tang and colleagues performed a sort of target fishing investigation by designing and synthesizing a biotinylated version of ebselen. When given to HeLa cell lysates, biotinylated ebselen was able to bind 462 proteins [173]. If from one side this peculiar chemical reactivity biases the perception of ebselen and its analogues in the medicinal chemistry community, one has to consider that this lack of specificity does not correspond with toxicity, ebselen being tested in several clinical trials without showing signs of acute or long-term toxicity. In the authors' opinion, while ebselen is well suited as a pharmacological tool, the benzisoselenazolone scaffold offers a unique opportunity to design compounds able to potently, likely covalently, inhibit proteins containing cysteines in strategic positions without exerting toxic effects.

Author Contributions: Conceptualization, L.S. and C.S. (Claudio Santi); methodology, L.S.; investigation, L.S. and C.S. (Cecilia Scimmi); resources, C.S. (Claudio Santi); data curation, L.S.; writingoriginal draft preparation, L.S.; writing—review and editing, C.S. (Claudio Santi); supervision, L.S.; funding acquisition, C.S. (Claudio Santi). All authors have read and agreed to the published version of the manuscript.

Funding: This research was funded by Università degli studi di Perugia, Fondo ricercar di base 2019.

Institutional Review Board Statement: Not applicable.

Informed Consent Statement: Not applicable.

Acknowledgments: This work has been carried out in the frame of the international Network "Selenium, Sulfur, Redox and Catalysis (SeSRedCat).

Conflicts of Interest: The authors declare no conflict of interest.

\section{References}

1. Lesser, R.; Weiss, R. Über selenhaltige aromatische Verbindungen (VI). Ber. Dtsch. Chem. Ges. 1924, 57, 1077-1082. [CrossRef]

2. Müller, A.; Cadenas, E.; Graf, P.; Sies, H. A novel biologically active seleno-organic compound-1. Glutathione peroxidase-like activity in vitro and antioxidant capacity of PZ 51 (Ebselen). Biochem. Pharmacol. 1984, 33, 3235-3239. [CrossRef]

3. Sands, K.N.; Back, T.G. Key steps and intermediates in the catalytic mechanism for the reduction of peroxides by the antioxidant ebselen. Tetrahedron 2018, 74, 4959-4967. [CrossRef] 
4. Rotruck, J.T.; Pope, A.L.; Ganther, H.E.; Swanson, A.B.; Hafeman, D.G.; Hoekstra, W.G. Selenium: Biochemical Role as a Component of Glutathione Peroxidase. Science 1973, 179, 588-590. [CrossRef]

5. Flohe, L.; Günzler, W.A.; Schock, H.H. Glutathione peroxidase: A selenoenzyme. FEBS Lett. 1973, 32, 132-134. [CrossRef]

6. Sies, H. Oxidative stress: A concept in redox biology and medicine. Redox Biol. 2015, 4, 180-183. [CrossRef]

7. Lenardão, E.J.; Santi, C.; Sancineto, L. Bioactive Organoselenium Compounds and Therapeutic Perspectives. In Neww Frontiers in Organoselenium Compounds; Springer International Publishing: Cham, Switzerland, 2018; pp. 99-143.

8. Azad, G.K.; Tomar, R.S. Ebselen, a promising antioxidant drug: Mechanisms of action and targets of biological pathways. Mol. Biol. Rep. 2014, 41, 4865-4879. [CrossRef] [PubMed]

9. Pacuła, A.J.; Mangiavacchi, F.; Sancineto, L.; Lenardão, E.J.; Ścianowski, J.; Santi, C. An Update on "Selenium Containing Compounds from Poison to Drug Candidates: A Review on the GPx-like Activity. Curr. Chem. Biol. 2016, 9, 97-112. [CrossRef]

10. Ren, X.; Zou, L.; Lu, J.; Holmgren, A. Selenocysteine in mammalian thioredoxin reductase and application of ebselen as a therapeutic. Free Radic. Biol. Med. 2018, 127, 238-247. [CrossRef] [PubMed]

11. Benelli, J.L.; Poester, V.R.; Munhoz, L.S.; Melo, A.M.; Trápaga, M.R.; Stevens, D.A.; Xavier, M.O. Ebselen and diphenyl diselenide against fungal pathogens: A systematic review. Med. Mycol. 2021, 59, 409-421. [CrossRef] [PubMed]

12. Sies, H.; Parnham, M.J. Potential therapeutic use of ebselen for COVID-19 and other respiratory viral infections. Free Radic. Biol. Med. 2020, 156, 107-112. [CrossRef]

13. Christiaens, L.; Welter, A.; Wirtz, P. New benzisoselenazolones, process for producing the same and pharmaceutical preparations containing the same. EP0044453A2, 27 January 1982.

14. Cantineau, R.; Tihange, G.; Plenevaux, A.; Christiaens, L.; Guillaume, M.; Welter, A.; Dereu, N. Synthesis of 75Se-2-phenyl-1,2benzisoselenazol-3(2H)-one (PZ 51; ebselen. A novel biologically active organo-selenium compound. J. Label. Compd. Radiopharm. 1986, 23, 59-65. [CrossRef]

15. Begini, F.; Krasowska, D.; Jasiak, A.; Drabowicz, J.; Santi, C.; Sancineto, L. Continuous flow synthesis of 2,2'-diselenobis(benzoic acid) and derivatives. React. Chem. Eng. 2020, 5, 641-644. [CrossRef]

16. Krasowska, D.; Begini, F.; Santi, C.; Mangiavacchi, F.; Drabowicz, J.; Sancineto, L. Ultrasound-assisted synthesis of alkali metals diselenides (M2Se2) and their application for the gram-scale preparation of 2,2'-diselenobis(benzoic acid). Arkivoc 2019, 2019, 24-37. [CrossRef]

17. Bartolini, D.; Commodi, J.; Piroddi, M.; Incipini, L.; Sancineto, L.; Santi, C.; Galli, F. Glutathione S-transferase pi expression regulates the Nrf2-dependent response to hormetic diselenides. Free Radic. Biol. Med. 2015, 88, 466-480. [CrossRef] [PubMed]

18. Küppers, J.; Schulz-Fincke, A.; Palus, J.; Giurg, M.; Skarżewski, J.; Gütschow, M. Convergent Synthesis of Two Fluorescent Ebselen-Coumarin Heterodimers. Pharmaceuticals 2016, 9, 43. [CrossRef] [PubMed]

19. Pietka-Ottlik, M.; Potaczek, P.; Piasecki, E.; Mlochowski, J. Crucial Role of Selenium in the Virucidal Activity of Benzisoselenazol3(2H)-ones and Related Diselenides. Molecules 2010, 15, 8214-8228. [CrossRef]

20. Piętka-Ottlik, M.; Wójtowicz-Młochowska, H.; Kołodziejczyk, K.; Piasecki, E.; Młochowski, J. New Organoselenium Compounds Active against Pathogenic Bacteria, Fungi and Viruses. Chem. Pharm. Bull. (Tokyo) 2008, 56, 1423-1427. [CrossRef] [PubMed]

21. Osajda, M.; Młochowski, J. The reactions of 2-(chloroseleno)benzoyl chloride with nucleophiles. Tetrahedron 2002, 58, 7531-7537. [CrossRef]

22. Kloc, K.; Maliszewska, I.; Młochowski, J. Synthesis of 7-Azabenzisoselenazol-3(2H)-ones: A New Group of Selenium Containing Antimicrobials. Synth. Commun. 2003, 33, 3805-3815. [CrossRef]

23. Luo, Z.; Liang, L.; Sheng, J.; Pang, Y.; Li, J.; Huang, L.; Li, X. Synthesis and biological evaluation of a new series of ebselen derivatives as glutathione peroxidase (GPx) mimics and cholinesterase inhibitors against Alzheimer's disease. Bioorg. Med. Chem. 2014, 22, 1355-1361. [CrossRef] [PubMed]

24. Obieziurska, M.; Pacuła, A.J.; Długosz-Pokorska, A.; Krzemiński, M.; Janecka, A.; Ścianowski, J. Bioselectivity Induced by Chirality of New Terpenyl Organoselenium Compounds. Materials 2019, 12, 3579. [CrossRef] [PubMed]

25. Engman, L.; Hallberg, A. Expedient synthesis of ebselen and related compounds. J. Org. Chem. 1989, 54, 2964-2966. [CrossRef]

26. Oppenheimer, J.; Silks, L.A. Synthesis of 2-phenyl-1,2-benziso [ ${ }^{77}$ Se]selenazol-3(2H)-one: “Ebselen". J. Label. Compd. Radiopharm. 1996, 38, 281-284. [CrossRef]

27. Chang, T.-C.; Huang, M.-L.; Hsu, W.-L.; Hwang, J.-M.; Hsu, L.-Y. Synthesis and Biological Evaluation of Ebselen and Its Acyclic Derivatives. Chem. Pharm. Bull. 2003, 51, 1413-1416. [CrossRef] [PubMed]

28. Zade, S.S.; Panda, S.; Singh, H.B.; Wolmershäuser, G. Synthesis of diaryl selenides using the in situ reagent SeCl2. Tetrahedron Lett. 2005, 46, 665-669. [CrossRef]

29. Sancineto, L.; Mariotti, A.; Bagnoli, L.; Marini, F.; Desantis, J.; Iraci, N.; Santi, C.; Pannecouque, C.; Tabarrini, O. Design and Synthesis of DiselenoBisBenzamides (DISeBAs) as Nucleocapsid Protein 7 (NCp7) Inhibitors with anti-HIV Activity. J. Med. Chem. 2015, 58, 9601-9614. [CrossRef]

30. Iraci, N.; Tabarrini, O.; Santi, C.; Sancineto, L. NCp7: Targeting a multitask protein for next-generation anti-HIV drug development part 2. Noncovalent inhibitors and nucleic acid binders. Drug Discov. Today 2018, 23, 687-695. [CrossRef] [PubMed]

31. Sancineto, L.; Iraci, N.; Tabarrini, O.; Santi, C. NCp7: Targeting a multitasking protein for next-generation anti-HIV drug development part 1: Covalent inhibitors. Drug Discov. Today 2018, 23, 260-271. [CrossRef] 
32. Nascimento, V.; Cordeiro, P.S.; Arca, M.; Marini, F.; Sancineto, L.; Braga, A.L.; Lippolis, V.; Iwaoka, M.; Santi, C. Fast and easy conversion of ortho amidoaryldiselenides into the corresponding ebselen-like derivatives driven by theoretical investigations. New J. Chem. 2020, 44, 9444-9451. [CrossRef]

33. Lambert, C.; Hilbert, M.; Christiaens, L.; Dereu, N. Ortholithiation As a Tool for the Synthesis of Ebselen Analogues. Synth. Commun. 1991, 21, 85-98. [CrossRef]

34. Zade, S.S.; Panda, S.; Tripathi, S.K.; Singh, H.B.; Wolmershäuser, G. Convenient Synthesis, Characterization and GPx-Like Catalytic Activity of Novel Ebselen Derivatives. Eur. J. Org. Chem. 2004, 2004, 3857-3864. [CrossRef]

35. Singh, V.P.; Poon, J.; Yan, J.; Lu, X.; Ott, M.K.; Butcher, R.J.; Gates, P.J.; Engman, L. Nitro-, Azo-, and Amino Derivatives of Ebselen: Synthesis, Structure, and Cytoprotective Effects. J. Org. Chem. 2017, 82, 313-321. [CrossRef]

36. Balkrishna, S.J.; Bhakuni, B.S.; Chopra, D.; Kumar, S. Cu-Catalyzed Efficient Synthetic Methodology for Ebselen and Related Se-N Heterocycles. Org. Lett. 2010, 12, 5394-5397. [CrossRef] [PubMed]

37. Balkrishna, S.J.; Bhakuni, B.S.; Kumar, S. Copper catalyzed/mediated synthetic methodology for ebselen and related isoselenazolones. Tetrahedron 2011, 67, 9565-9575. [CrossRef]

38. Balkrishna, S.J.; Kumar, S.; Azad, G.K.; Bhakuni, B.S.; Panini, P.; Ahalawat, N.; Tomar, R.S.; Detty, M.R.; Kumar, S. An ebselen like catalyst with enhanced GPx activity via a selenol intermediate. Org. Biomol. Chem. 2014, 12, 1215-1219. [CrossRef] [PubMed]

39. Thanna, S.; Goins, C.M.; Knudson, S.E.; Slayden, R.A.; Ronning, D.R.; Sucheck, S.J. Thermal and Photoinduced Copper-Promoted C-Se Bond Formation: Synthesis of 2-Alkyl-1,2-benzisoselenazol-3(2H)-ones and Evaluation against Mycobacterium tuberculosis. J. Org. Chem. 2017, 82, 3844-3854. [CrossRef]

40. Pacuła, A.J.; Ścianowski, J.; Aleksandrzak, K.B. Highly efficient synthesis and antioxidant capacity of N-substituted benzisoselenazol-3(2H)-ones. RSC Adv. 2014, 4, 48959-48962. [CrossRef]

41. Obieziurska, M.; Pacuła, A.; Juhas, U.; Antosiewicz, J.; Ścianowski, J. The Influence of O/S Exchange on the Biocatalytical Activity of Benzisoselenazol-3(2H)-ones. Catalysts 2018, 8, 493. [CrossRef]

42. Fong, M.C.; Schiesser, C.H. Intramolecular Homolytic Substitution with Amidyl Radicals: A Free-Radical Synthesis of Ebselen and Related Analogues. J. Org. Chem. 1997, 62, 3103-3108. [CrossRef] [PubMed]

43. Di Leo, I.; Messina, F.; Nascimento, V.; Nacca, F.G.; Pietrella, D.; Lenardão, E.J.; Perin, G.; Sancineto, L. Synthetic approaches to organoselenium derivatives with antimicrobial and anti-biofilm activity. Mini. Rev. Org. Chem. 2019, 16. [CrossRef]

44. Daolio, A.; Scilabra, P.; Di Pietro, M.E.; Resnati, C.; Rissanen, K.; Resnati, G. Binding motif of ebselen in solution: Chalcogen and hydrogen bonds team up. New J. Chem. 2020, 44, 20697-20703. [CrossRef]

45. Zhu, N.; Zhang, D.; Wang, W.; Li, X.; Yang, B.; Song, J.; Zhao, X.; Huang, B.; Shi, W.; Lu, R.; et al. A Novel Coronavirus from Patients with Pneumonia in China, 2019. N. Engl. J. Med. 2020, 382, 727-733. [CrossRef] [PubMed]

46. Jin, Z.; Du, X.; Xu, Y.; Deng, Y.; Liu, M.; Zhao, Y.; Zhang, B.; Li, X.; Zhang, L.; Peng, C.; et al. Structure of Mpro from SARS-CoV-2 and discovery of its inhibitors. Nature 2020, 582, 289-293. [CrossRef]

47. Haritha, C.V.; Sharun, K.; Jose, B. Ebselen, a new candidate therapeutic against SARS-CoV-2. Int. J. Surg. 2020, 84, 53-56. [CrossRef]

48. Ma, C.; Hu, Y.; Townsend, J.A.; Lagarias, P.I.; Marty, M.T.; Kolocouris, A.; Wang, J. Ebselen, Disulfiram, Carmofur, PX-12, Tideglusib, and Shikonin Are Nonspecific Promiscuous SARS-CoV-2 Main Protease Inhibitors. ACS Pharmacol. Transl. Sci. 2020, 3 , 1265-1277. [CrossRef] [PubMed]

49. Menéndez, C.A.; Byléhn, F.; Perez-Lemus, G.R.; Alvarado, W.; de Pablo, J.J. Molecular characterization of Ebselen binding activity to SARS-CoV-2 main protease. Sci. Adv. 2020, eabd3045. [CrossRef] [PubMed]

50. Nogara, P.A.; Omage, F.B.; Bolzan, G.R.; Delgado, C.P.; Aschner, M.; Orian, L.; Teixeira Rocha, J.B. In silico Studies on the Interaction Between Mpro and PLpro From SARS-CoV-2 and Ebselen, its Metabolites and Derivatives. Mol. Inform. 2021, 40, 2100028. [CrossRef]

51. Chen, T.; Fei, C.-Y.; Chen, Y.-P.; Sargsyan, K.; Chang, C.-P.; Yuan, H.S.; Lim, C. Synergistic Inhibition of SARS-CoV-2 Replication Using Disulfiram/Ebselen and Remdesivir. ACS Pharmacol. Transl. Sci. 2021, 4, 898-907. [CrossRef]

52. Weglarz-Tomczak, E.; Tomczak, J.M.; Talma, M.; Burda-Grabowska, M.; Giurg, M.; Brul, S. Identification of ebselen and its analogues as potent covalent inhibitors of papain-like protease from SARS-CoV-2. Sci. Rep. 2021, 11, 3640. [CrossRef]

53. Sun, L.-Y.; Chen, C.; Su, J.; Li, J.-Q.; Jiang, Z.; Gao, H.; Chigan, J.-Z.; Ding, H.-H.; Zhai, L.; Yang, K.-W. Ebsulfur and Ebselen as highly potent scaffolds for the development of potential SARS-CoV-2 antivirals. Bioorg. Chem. 2021, 112, 104889. [CrossRef] [PubMed]

54. Amporndanai, K.; Meng, X.; Shang, W.; Jin, Z.; Rogers, M.; Zhao, Y.; Rao, Z.; Liu, Z.-J.; Yang, H.; Zhang, L.; et al. Inhibition mechanism of SARS-CoV-2 main protease by ebselen and its derivatives. Nat. Commun. 2021, 12, 3061. [CrossRef]

55. Castel, A.D.; Wilbourn, B.; Magnus, M.; Greenberg, A.E. SARS-CoV-2 and HIV: Epidemiology, Treatment, and Lessons Learned from HIV. Aids Rev. 2020, 22, 133-142. [CrossRef]

56. Thenin-Houssier, S.; de Vera, I.M.S.; Pedro-Rosa, L.; Brady, A.; Richard, A.; Konnick, B.; Opp, S.; Buffone, C.; Fuhrmann, J.; Kota, S.; et al. Ebselen, a Small-Molecule Capsid Inhibitor of HIV-1 Replication. Antimicrob. Agents Chemother. 2016, 60, $2195-2208$. [CrossRef] [PubMed]

57. Zhang, D.-W.; Yan, H.-L.; Xu, X.-S.; Xu, L.; Yin, Z.-H.; Chang, S.; Luo, H. The selenium-containing drug ebselen potently disrupts LEDGF/p75-HIV-1 integrase interaction by targeting LEDGF/p75. J. Enzyme Inhib. Med. Chem. 2020, 35, 906-912. [CrossRef] 
58. Gualano, R.C.; Hansen, M.J.; Vlahos, R.; Jones, J.E.; Park-Jones, R.A.; Deliyannis, G.; Turner, S.J.; Duca, K.A.; Anderson, G.P. Cigarette smoke worsens lung inflammation and impairs resolution of influenza infection in mice. Respir. Res. 2008, 9, 53. [CrossRef]

59. Belvisi, M.G.; Haddad, E.-B.; Battram, C.; Birrell, M.; Foster, M.; Webber, S. Anti-inflammatory properties of ebselen in a model of sephadex-induced lung inflammation. Eur. Respir. J. 2000, 15, 579-581. [CrossRef] [PubMed]

60. Haddad, E.-B.; McCluskie, K.; Birrell, M.A.; Dabrowski, D.; Pecoraro, M.; Underwood, S.; Chen, B.; De Sanctis, G.T.; Webber, S.E.; Foster, M.L.; et al. Differential Effects of Ebselen on Neutrophil Recruitment, Chemokine, and Inflammatory Mediator Expression in a Rat Model of Lipopolysaccharide-Induced Pulmonary Inflammation. J. Immunol. 2002, 169, 974-982. [CrossRef] [PubMed]

61. Oostwoud, L.C.; Gunasinghe, P.; Seow, H.J.; Ye, J.M.; Selemidis, S.; Bozinovski, S.; Vlahos, R. Apocynin and ebselen reduce influenza A virus-induced lung inflammation in cigarette smoke-exposed mice. Sci. Rep. 2016, 6, 20983. [CrossRef]

62. Brassington, K.; Chan, S.M.H.; Seow, H.J.; Dobric, A.; Bozinovski, S.; Selemidis, S.; Vlahos, R. Ebselen reduces cigarette smoke-induced endothelial dysfunction in mice. Br. J. Pharmacol. 2021, 178, 1805-1818. [CrossRef]

63. Petersen, L.R.; Jamieson, D.J.; Powers, A.M.; Honein, M.A. Zika Virus. N. Engl. J. Med. 2016, 374, 1552-1563. [CrossRef] [PubMed]

64. Plourde, A.R.; Bloch, E.M. A Literature Review of Zika Virus. Emerg. Infect. Dis. 2016, 22, 1185-1192. [CrossRef] [PubMed]

65. Govero, J.; Esakky, P.; Scheaffer, S.M.; Fernandez, E.; Drury, A.; Platt, D.J.; Gorman, M.J.; Richner, J.M.; Caine, E.A.; Salazar, V.; et al. Zika virus infection damages the testes in mice. Nature 2016, 540, 438-442. [CrossRef]

66. Simanjuntak, Y.; Liang, J.-J.; Chen, S.-Y.; Li, J.-K.; Lee, Y.-L.; Wu, H.-C.; Lin, Y.-L. Ebselen alleviates testicular pathology in mice with Zika virus infection and prevents its sexual transmission. PLoS Pathog. 2018, 14, e1006854. [CrossRef] [PubMed]

67. Giurg, M.; Gołąb, A.; Suchodolski, J.; Kaleta, R.; Krasowska, A.; Piasecki, E.; Piętka-Ottlik, M. Reaction of bis[(2chlorocarbonyl)phenyl] Diselenide with Phenols, Aminophenols, and Other Amines towards Diphenyl Diselenides with Antimicrobial and Antiviral Properties. Molecules 2017, 22, 974. [CrossRef]

68. Gustafsson, T.N.; Osman, H.; Werngren, J.; Hoffner, S.; Engman, L.; Holmgren, A. Ebselen and analogs as inhibitors of Bacillus anthracis thioredoxin reductase and bactericidal antibacterials targeting Bacillus species, Staphylococcus aureus and Mycobacterium tuberculosis. Biochim. Biophys. Acta Gen. Subj. 2016, 1860, 1265-1271. [CrossRef] [PubMed]

69. Dong, C.; Zhou, J.; Wang, P.; Li, T.; Zhao, Y.; Ren, X.; Lu, J.; Wang, J.; Holmgren, A.; Zou, L. Topical Therapeutic Efficacy of Ebselen Against Multidrug-Resistant Staphylococcus aureus LT-1 Targeting Thioredoxin Reductase. Front. Microbiol. 2020, 10. [CrossRef] [PubMed]

70. AbdelKhalek, A.; Abutaleb, N.S.; Mohammad, H.; Seleem, M.N. Repurposing ebselen for decolonization of vancomycin-resistant enterococci (VRE). PLoS ONE 2018, 13, e0199710. [CrossRef]

71. Mohammad, H.; Abutaleb, N.S.; Dieterly, A.M.; Lyle, L.T.; Seleem, M.N. Evaluation of ebselen in resolving a methicillin-resistant Staphylococcus aureus infection of pressure ulcers in obese and diabetic mice. PLoS ONE 2021, 16, e0247508. [CrossRef]

72. Sancineto, L.; Piccioni, M.; De Marco, S.; Pagiotti, R.; Nascimento, V.; Braga, A.L.; Santi, C.; Pietrella, D. Diphenyl diselenide derivatives inhibit microbial biofilm formation involved in wound infection. BMC Microbiol. 2016, 16, 220. [CrossRef]

73. Leffler, D.A.; Lamont, J.T. Clostridium difficile Infection. N. Engl. J. Med. 2015, 372, 1539-1548. [CrossRef] [PubMed]

74. Schubert, A.M.; Rogers, M.A.M.; Ring, C.; Mogle, J.; Petrosino, J.P.; Young, V.B.; Aronoff, D.M.; Schloss, P.D. Microbiome Data Distinguish Patients with Clostridium difficile Infection and Non-C. difficile-Associated Diarrhea from Healthy Controls. MBio 2014, 5, e01021-14. [CrossRef]

75. Bender, K.O.; Garland, M.; Ferreyra, J.A.; Hryckowian, A.J.; Child, M.A.; Puri, A.W.; Solow-Cordero, D.E.; Higginbottom, S.K.; Segal, E.; Banaei, N.; et al. A small-molecule antivirulence agent for treating Clostridium difficile infection. Sci. Transl. Med. 2015, 7, 306ra148. [CrossRef] [PubMed]

76. Garland, M.; Hryckowian, A.J.; Tholen, M.; Oresic Bender, K.; Van Treuren, W.W.; Loscher, S.; Sonnenburg, J.L.; Bogyo, M. The Clinical Drug Ebselen Attenuates Inflammation and Promotes Microbiome Recovery in Mice after Antibiotic Treatment for CDI. Cell Rep. Med. 2020, 1, 100005. [CrossRef]

77. Smith, P.A.; Koehler, M.F.T.; Girgis, H.S.; Yan, D.; Chen, Y.; Chen, Y.; Crawford, J.J.; Durk, M.R.; Higuchi, R.I.; Kang, J.; et al. Optimized arylomycins are a new class of Gram-negative antibiotics. Nature 2018, 561, 189-194. [CrossRef]

78. Richter, M.F.; Hergenrother, P.J. The challenge of converting Gram-positive-only compounds into broad-spectrum antibiotics. Ann. N. Y. Acad. Sci. 2019, 1435, 18-38. [CrossRef]

79. Chen, C.; Yang, K. Ebselen bearing polar functionality: Identification of potent antibacterial agents against multidrug-resistant Gram-negative bacteria. Bioorg. Chem. 2019, 93, 103286. [CrossRef]

80. Jin, W.B.; Xu, C.; Cheung, Q.; Gao, W.; Zeng, P.; Liu, J.; Chan, E.W.C.; Leung, Y.-C.; Chan, T.H.; Wong, K.-Y.; et al. Bioisosteric investigation of ebselen: Synthesis and in vitro characterization of 1,2-benzisothiazol-3(2H)-one derivatives as potent New Delhi metallo- $\beta$-lactamase inhibitors. Bioorg. Chem. 2020, 100, 103873. [CrossRef] [PubMed]

81. Jin, W.B.; Xu, C.; Cheng, Q.; Qi, X.L.; Gao, W.; Zheng, Z.; Chan, E.W.C.; Leung, Y.-C.; Chan, T.H.; Wong, K.-Y.; et al. Investigation of synergistic antimicrobial effects of the drug combinations of meropenem and 1,2-benzisoselenazol-3(2H)-one derivatives on carbapenem-resistant Enterobacteriaceae producing NDM-1. Eur. J. Med. Chem. 2018, 155, 285-302. [CrossRef]

82. Chiou, J.; Wan, S.; Chan, K.-F.; So, P.-K.; He, D.; Chan, E.W.; Chan, T.; Wong, K.; Tao, J.; Chen, S. Ebselen as a potent covalent inhibitor of New Delhi metallo- $\beta$-lactamase (NDM-1). Chem. Commun. 2015, 51, 9543-9546. [CrossRef]

83. Zou, L.; Lu, J.; Wang, J.; Ren, X.; Zhang, L.; Gao, Y.; Rottenberg, M.E.; Holmgren, A. Synergistic antibacterial effect of silver and ebselen against multidrug-resistant Gram-negative bacterial infections. EMBO Mol. Med. 2017. [CrossRef] 
84. Wang, P.; Wang, J.; Xie, Z.; Zhou, J.; Lu, Q.; Zhao, Y.; Dong, C.; Zou, L. Depletion of multidrug-resistant uropathogenic Escherichia coli BC1 by ebselen and silver ion. J. Cell. Mol. Med. 2020, 24, 13139-13150. [CrossRef] [PubMed]

85. Klockgether, J.; Tümmler, B. Recent advances in understanding Pseudomonas aeruginosa as a pathogen. F1000Research 2017, 6, 1261. [CrossRef]

86. Malhotra, S.; Hayes, D.; Wozniak, D.J. Cystic Fibrosis and Pseudomonas aeruginosa: The Host-Microbe Interface. Clin. Microbiol Rev. 2019, 32. [CrossRef]

87. Martin, D.W.; Schurr, M.J.; Mudd, M.H.; Govan, J.R.; Holloway, B.W.; Deretic, V. Mechanism of conversion to mucoidy in Pseudomonas aeruginosa infecting cystic fibrosis patients. Proc. Natl. Acad. Sci. USA 1993, 90, 8377-8381. [CrossRef]

88. Kim, S.-K.; Ngo, H.X.; Dennis, E.K.; Thamban Chandrika, N.; DeShong, P.; Garneau-Tsodikova, S.; Lee, V.T. Inhibition of Pseudomonas aeruginosa Alginate Synthesis by Ebselen Oxide and Its Analogues. ACS Infect. Dis. 2021, 7, 1713-1726. [CrossRef] [PubMed]

89. Loewenberg, S. India reports cases of totally drug-resistant tuberculosis. Lancet 2012, 379, 205. [CrossRef]

90. Favrot, L.; Grzegorzewicz, A.E.; Lajiness, D.H.; Marvin, R.K.; Boucau, J.; Isailovic, D.; Jackson, M.; Ronning, D.R. Mechanism of inhibition of Mycobacterium tuberculosis antigen 85 by ebselen. Nat. Commun. 2013, 4, 2748. [CrossRef]

91. Goins, C.M.; Dajnowicz, S.; Thanna, S.; Sucheck, S.J.; Parks, J.M.; Ronning, D.R. Exploring Covalent Allosteric Inhibition of Antigen 85C from Mycobacterium tuberculosis by Ebselen Derivatives. ACS Infect. Dis. 2017, 3, 378-387. [CrossRef]

92. de Munnik, M.; Lohans, C.T.; Lang, P.A.; Langley, G.W.; Malla, T.R.; Tumber, A.; Schofield, C.J.; Brem, J. Targeting the Mycobacterium tuberculosis transpeptidase Ldt Mt2 with cysteine-reactive inhibitors including ebselen. Chem. Commun. 2019, 55, 10214-10217. [CrossRef]

93. Tirado-Sánchez, A.; González, G.M.; Bonifaz, A. Endemic mycoses: Epidemiology and diagnostic strategies. Expert Rev. Anti. Infect. Ther. 2020, 18, 1105-1117. [CrossRef]

94. Galant, L.S.; Braga, M.M.; de Souza, D.; de Bem, A.F.; Sancineto, L.; Santi, C.; da Rocha, J.B.T. Induction of reactive oxygen species by diphenyl diselenide is preceded by changes in cell morphology and permeability in Saccharomyces cerevisiae. Free Radic. Res. 2017. [CrossRef]

95. Thangamani, S.; Eldesouky, H.E.; Mohammad, H.; Pascuzzi, P.E.; Avramova, L.; Hazbun, T.R.; Seleem, M.N. Ebselen exerts antifungal activity by regulating glutathione (GSH) and reactive oxygen species (ROS) production in fungal cells. Biochim. Biophys. Acta Gen. Subj. 2017, 1861, 3002-3010. [CrossRef]

96. Orie, N.N.; Warren, A.R.; Basaric, J.; Lau-Cam, C.; Piętka-Ottlik, M.; Młochowski, J.; Billack, B. In vitro assessment of the growth and plasma membrane $\mathrm{H}+$-ATPase inhibitory activity of ebselen and structurally related selenium- and sulfur-containing compounds in Candida albicans. J. Biochem. Mol. Toxicol. 2017, 31, e21892. [CrossRef] [PubMed]

97. Vartak, R.; Menon, S.; Patki, M.; Billack, B.; Patel, K. Ebselen nanoemulgel for the treatment of topical fungal infection. Eur. J. Pharm. Sci. 2020, 148, 105323. [CrossRef] [PubMed]

98. Chowdhary, A.; Sharma, C.; Meis, J.F. Candida auris: A rapidly emerging cause of hospital-acquired multidrug-resistant fungal infections globally. PLoS Pathog. 2017, 13, e1006290. [CrossRef]

99. Wall, G.; Chaturvedi, A.K.; Wormley, F.L.; Wiederhold, N.P.; Patterson, H.P.; Patterson, T.F.; Lopez-Ribot, J.L. Screening a Repurposing Library for Inhibitors of Multidrug-Resistant Candida auris Identifies Ebselen as a Repositionable Candidate for Antifungal Drug Development. Antimicrob. Agents Chemother. 2018, 62, e01084-18. [CrossRef]

100. Büscher, P.; Cecchi, G.; Jamonneau, V.; Priotto, G. Human African trypanosomiasis. Lancet 2017, 390, 2397-2409. [CrossRef]

101. Joice, A.C.; Harris, M.T.; Kahney, E.W.; Dodson, H.C.; Maselli, A.G.; Whitehead, D.C.; Morris, J.C. Exploring the mode of action of ebselen in Trypanosoma brucei hexokinase inhibition. Int. J. Parasitol. Drugs Drug Resist. 2013, 3, 154-160. [CrossRef]

102. Gordhan, H.M.; Patrick, S.L.; Swasy, M.I.; Hackler, A.L.; Anayee, M.; Golden, J.E.; Morris, J.C.; Whitehead, D.C. Evaluation of substituted ebselen derivatives as potential trypanocidal agents. Bioorg. Med. Chem. Lett. 2017, 27, 537-541. [CrossRef] [PubMed]

103. Feng, Y.; Xiao, L. Molecular Epidemiology of Cryptosporidiosis in China. Front. Microbiol. 2017, 8. [CrossRef]

104. Eltahan, R.; Guo, F.; Zhang, H.; Xiang, L.; Zhu, G. Discovery of ebselen as an inhibitor of Cryptosporidium parvum glucose-6phosphate isomerase (CPGPI) by high-throughput screening of existing drugs. Int. J. Parasitol. Drugs Drug Resist. 2018, 8, 43-49. [CrossRef]

105. Debnath, A.; Nelson, A.T.; Silva-Olivares, A.; Shibayama, M.; Siegel, D.; McKerrow, J.H. In Vitro Efficacy of Ebselen and BAY 11-7082 Against Naegleria fowleri. Front. Microbiol. 2018, 9, 1-8. [CrossRef]

106. Sung, H.; Ferlay, J.; Siegel, R.L.; Laversanne, M.; Soerjomataram, I.; Jemal, A.; Bray, F. Global Cancer Statistics 2020: GLOBOCAN Estimates of Incidence and Mortality Worldwide for 36 Cancers in 185 Countries. CA. Cancer J. Clin. 2021, 71, 209-249. [CrossRef] [PubMed]

107. Krasowska, D.; Iraci, N.; Santi, C.; Drabowicz, J.; Cieslak, M.; Kaźmierczak-Barańska, J.; Palomba, M.; Królewska-Golińska, K.; Magiera, J.; Sancineto, L. Diselenides and Benzisoselenazolones as Antiproliferative Agents and Glutathione-S-Transferase Inhibitors. Molecules 2019, 24, 2914. [CrossRef]

108. Bartolini, D.; Sancineto, L.; Fabro de Bem, A.; Tew, K.D.; Santi, C.; Radi, R.; Toquato, P.; Galli, F. Selenocompounds in Cancer Therapy: An Overview. Adv. Cancer Res. 2017, 36, 259-302.

109. Plano, D.; Karelia, D.N.; Pandey, M.K.; Spallholz, J.E.; Amin, S.; Sharma, A.K. Design, Synthesis, and Biological Evaluation of Novel Selenium (Se-NSAID) Molecules as Anticancer Agents. J. Med. Chem. 2016, 59, 1946-1959. [CrossRef] 
110. Romano, B.; Plano, D.; Encío, I.; Palop, J.A.; Sanmartín, C. In vitro radical scavenging and cytotoxic activities of novel hybrid selenocarbamates. Bioorg. Med. Chem. 2015, 23, 1716-1727. [CrossRef]

111. Ruberte, A.C.; Sanmartin, C.; Aydillo, C.; Sharma, A.K.; Plano, D. Development and Therapeutic Potential of Selenazo Compounds. J. Med. Chem. 2020, 63, 1473-1489. [CrossRef] [PubMed]

112. Radomska, D.; Czarnomysy, R.; Radomski, D.; Bielawski, K. Selenium Compounds as Novel Potential Anticancer Agents. Int. J. Mol. Sci. 2021, 22, 1009. [CrossRef]

113. Nogueira, C.W.; Barbosa, N.V.; Rocha, J.B.T. Toxicology and pharmacology of synthetic organoselenium compounds: An update. Arch. Toxicol. 2021, 95, 1179-1226. [CrossRef] [PubMed]

114. Wang, L.; Yang, Z.; Fu, J.; Yin, H.; Xiong, K.; Tan, Q.; Jin, H.; Li, J.; Wang, T.; Tang, W.; et al. Ethaselen: A potent mammalian thioredoxin reductase 1 inhibitor and novel organoselenium anticancer agent. Free Radic. Biol. Med. 2012, 52, 898-908. [CrossRef]

115. Lu, J.; Vlamis-Gardikas, A.; Kandasamy, K.; Zhao, R.; Gustafsson, T.N.; Engstrand, L.; Hoffner, S.; Engman, L.; Holmgren, A. Inhibition of bacterial thioredoxin reductase: An antibiotic mechanism targeting bacteria lacking glutathione. FASEB J. 2013, 27, 1394-1403. [CrossRef]

116. Koh, W.X.; Coppo, L.; Ganguly, R.; Holmgren, A.; Leong, W.K. Metallocenyl derivatives of ebselen are selective and competitive inhibitors of thioredoxin reductase. J. Organomet. Chem. 2021, 943, 121822. [CrossRef]

117. Santofimia-Castaño, P.; Izquierdo-Alvarez, A.; Plaza-Davila, M.; Martinez-Ruiz, A.; Fernandez-Bermejo, M.; Mateos-Rodriguez, J.M.; Salido, G.M.; Gonzalez, A. Ebselen impairs cellular oxidative state and induces endoplasmic reticulum stress and activation of crucial mitogen-activated protein kinases in pancreatic tumour AR42J cells. J. Cell. Biochem. 2018, 119, 1122-1133. [CrossRef] [PubMed]

118. Feng, Q.; Li, X.; Sun, W.; Li, Y.; Yuan, Y.; Guan, B.; Zhang, S. Discovery of Ebselen as an Inhibitor of 6PGD for Suppressing Tumor Growth. Cancer Manag. Res. 2020, 12, 6921-6934. [CrossRef]

119. Choudhary, C.; Kumar, C.; Gnad, F.; Nielsen, M.L.; Rehman, M.; Walther, T.C.; Olsen, J.V.; Mann, M. Lysine Acetylation Targets Protein Complexes and Co-Regulates Major Cellular Functions. Science 2009, 325, 834-840. [CrossRef] [PubMed]

120. Wang, Y.; Wallach, J.; Duane, S.; Wang, Y.; Wu, J.; Wang, J.; Adejare, A.; Ma, H. Developing selective histone deacetylases (HDACs) inhibitors through ebselen and analogs. Drug Des. Dev. Ther. 2017, 11, 1369-1382. [CrossRef] [PubMed]

121. Pacuła, A.J.; Kaczor, K.B.; Antosiewicz, J.; Janecka, A.; Długosz, A.; Janecki, T.; Wojtczak, A.; Ścianowski, J. New Chiral Ebselen Analogues with Antioxidant and Cytotoxic Potential. Molecules 2017, 22, 492. [CrossRef]

122. Pacuła, A.J.; Kaczor, K.B.; Wojtowicz, A.; Antosiewicz, J.; Janecka, A.; Długosz, A.; Janecki, T.; Ścianowski, J. New glutathione peroxidase mimetics-Insights into antioxidant and cytotoxic activity. Bioorg. Med. Chem. 2017, 25, 126-131. [CrossRef] [PubMed]

123. Kaczor-Keller, K.B.; Pawlik, A.; Scianowski, J.; Pacuła, A.; Obieziurska, M.; Marcheggiani, F.; Cirilli, I.; Tiano, L.; Antosiewicz, J. In Vitro Anti-Prostate Cancer Activity of Two Ebselen Analogues. Pharmaceuticals 2020, 13, 47. [CrossRef]

124. Elsherbini, M.; Hamama, W.S.; Zoorob, H.H. An Easy Synthetic Approach to Construct Some Ebselen Analogues and Benzo[b]selenophene Derivatives: Their Antioxidant and Cytotoxic Assessment. J. Heterocycl. Chem. 2018, 55, 1645-1650. [CrossRef]

125. Thabet, N.M.; Moustafa, E.M. Synergistic effect of Ebselen and gamma radiation on breast cancer cells. Int. J. Radiat. Biol. 2017, 93, 784-792. [CrossRef]

126. Alzheimer's Association. 2020 Alzheimer's disease facts and figures. Alzheimer's Dement. 2020, 16, 391-460. [CrossRef]

127. Scarpini, E.; Schelterns, P.; Feldman, H. Treatment of Alzheimer's disease; current status and new perspectives. Lancet Neurol. 2003, 2, 539-547. [CrossRef]

128. Xie, Y.; Tan, Y.; Zheng, Y.; Du, X.; Liu, Q. Ebselen ameliorates $\beta$-amyloid pathology, tau pathology, and cognitive impairment in triple-transgenic Alzheimer's disease mice. JBIC J. Biol. Inorg. Chem. 2017, 22, 851-865. [CrossRef]

129. Martini, F.; Pesarico, A.P.; Brüning, C.A.; Zeni, G.; Nogueira, C.W. Ebselen inhibits the activity of acetylcholinesterase globular isoform G4 in vitro and attenuates scopolamine-induced amnesia in mice. J. Cell. Biochem. 2018, 119, 5598-5608. [CrossRef]

130. Martini, F.; Rosa, S.G.; Klann, I.P.; Fulco, B.C.W.; Carvalho, F.B.; Rahmeier, F.L.; Fernandes, M.C.; Nogueira, C.W. A multifunctional compound ebselen reverses memory impairment, apoptosis and oxidative stress in a mouse model of sporadic Alzheimer's disease. J. Psychiatr. Res. 2019, 109, 107-117. [CrossRef] [PubMed]

131. Klann, I.P.; Martini, F.; Rosa, S.G.; Nogueira, C.W. Ebselen reversed peripheral oxidative stress induced by a mouse model of sporadic Alzheimer's disease. Mol. Biol. Rep. 2020, 47, 2205-2215. [CrossRef] [PubMed]

132. Luo, Z.; Sheng, J.; Sun, Y.; Lu, C.; Yan, J.; Liu, A.; Luo, H.; Huang, L.; Li, X. Synthesis and Evaluation of Multi-Target-Directed Ligands against Alzheimer's Disease Based on the Fusion of Donepezil and Ebselen. J. Med. Chem. 2013, 56, 9089-9099. [CrossRef] [PubMed]

133. Morphy, R.; Kay, C.; Rankovic, Z. From magic bullets to designed multiple ligands. Drug Discov. Today 2004, 9, 641-651. [CrossRef]

134. Sancineto, L.; Iraci, N.; Barreca, M.L.; Massari, S.; Manfroni, G.; Corazza, G.; Cecchetti, V.; Marcello, A.; Daelemans, D.; Pannecouque, C.; et al. Exploiting the anti-HIV 6-desfluoroquinolones to design multiple ligands. Bioorg. Med. Chem. 2014, 22, 4658-4666. [CrossRef] [PubMed]

135. Ng, H.-L.; Chen, S.; Chew, E.-H.; Chui, W.-K. Applying the designed multiple ligands approach to inhibit dihydrofolate reductase and thioredoxin reductase for anti-proliferative activity. Eur. J. Med. Chem. 2016, 115, 63-74. [CrossRef] [PubMed]

136. Gattrell, W.; Johnstone, C.; Patel, S.; Smith, C.S.; Scheel, A.; Schindler, M. Designed multiple ligands in metabolic disease research: From concept to platform. Drug Discov. Today 2013, 18, 692-696. [CrossRef] [PubMed] 
137. Wang, Z.; Li, W.; Wang, Y.; Li, X.; Huang, L.; Li, X. Design, synthesis and evaluation of clioquinol-ebselen hybrids as multi-targetdirected ligands against Alzheimer's disease. RSC Adv. 2016, 6, 7139-7158. [CrossRef]

138. Landgraf, A.D.; Alsegiani, A.S.; Alaqel, S.; Thanna, S.; Shah, Z.A.; Sucheck, S.J. Neuroprotective and Anti-neuroinflammatory Properties of Ebselen Derivatives and Their Potential to Inhibit Neurodegeneration. ACS Chem. Neurosci. 2020, 11, 3008-3016. [CrossRef]

139. Roos, P.M. Metals and Motor Neuron Disease. In Biometals in Neurodegenerative Diseases; Academic Press: Cambridge, MA, USA, 2017; pp. 175-193.

140. Rosen, D.R.; Siddique, T.; Patterson, D.; Figlewicz, D.A.; Sapp, P.; Hentati, A.; Donaldson, D.; Goto, J.; O’Regan, J.P.; Deng, H.-X.; et al. Mutations in $\mathrm{Cu} / \mathrm{Zn}$ superoxide dismutase gene are associated with familial amyotrophic lateral sclerosis. Nature 1993, 362, 59-62. [CrossRef]

141. Capper, M.J.; Wright, G.S.A.; Barbieri, L.; Luchinat, E.; Mercatelli, E.; McAlary, L.; Yerbury, J.J.; O’Neill, P.M.; Antonyuk, S.V.; Banci, L.; et al. The cysteine-reactive small molecule ebselen facilitates effective SOD1 maturation. Nat. Commun. 2018, 9, 1693. [CrossRef]

142. Chantadul, V.; Wright, G.S.A.; Amporndanai, K.; Shahid, M.; Antonyuk, S.V.; Washbourn, G.; Rogers, M.; Roberts, N.; Pye, M.; O'Neill, P.M.; et al. Ebselen as template for stabilization of A4V mutant dimer for motor neuron disease therapy. Commun. Biol. 2020, 3, 97. [CrossRef]

143. Amporndanai, K.; Rogers, M.; Watanabe, S.; Yamanaka, K.; O’Neill, P.M.; Hasnain, S.S. Novel Selenium-based compounds with therapeutic potential for SOD1-linked amyotrophic lateral sclerosis. EBioMedicine 2020, 59, 102980. [CrossRef]

144. Geddes, J.R.; Goodwin, G.M.; Rendell, J.; Azorin, J.-M.; Cipriani, A.; Ostacher, M.J.; Morriss, R.; Alder, N.; Juszczak, E. Lithium plus valproate combination therapy versus monotherapy for relapse prevention in bipolar I disorder (BALANCE): A randomised open-label trial. Lancet 2010, 375, 385-395. [CrossRef] [PubMed]

145. Berridge, M.J.; Downes, C.P.; Hanley, M.R. Neural and developmental actions of lithium: A unifying hypothesis. Cell 1989, 59, 411-419. [CrossRef]

146. Singh, N.; Halliday, A.C.; Thomas, J.M.; Kuznetsova, O.V.; Baldwin, R.; Woon, E.C.Y.; Aley, P.K.; Antoniadou, I.; Sharp, T.; Vasudevan, S.R.; et al. A safe lithium mimetic for bipolar disorder. Nat. Commun. 2013, 4, 1332. [CrossRef]

147. Singh, N.; Sharpley, A.L.; Emir, U.E.; Masaki, C.; Herzallah, M.M.; Gluck, M.A.; Sharp, T.; Harmer, C.J.; Vasudevan, S.R.; Cowen, P.J.; et al. Effect of the Putative Lithium Mimetic Ebselen on Brain Myo-Inositol, Sleep, and Emotional Processing in Humans. Neuropsychopharmacology 2016, 41, 1768-1778. [CrossRef] [PubMed]

148. Masaki, C.; Sharpley, A.L.; Godlewska, B.R.; Berrington, A.; Hashimoto, T.; Singh, N.; Vasudevan, S.R.; Emir, U.E.; Churchill, G.C.; Cowen, P.J. Effects of the potential lithium-mimetic, ebselen, on brain neurochemistry: A magnetic resonance spectroscopy study at 7 tesla. Psychopharmacology (Berl.) 2016, 233, 1097-1104. [CrossRef]

149. Mota, F.; Sementa, T.; Taddei, C.; Moses, N.; Bordoloi, J.; Hader, S.; Eykyn, T.; Cash, D.; Turkheimer, F.; Veronese, M.; et al. Investigating the effects of ebselen, a potential new lithium mimetic, on glutamate transmission. Synapse 2020, 74 , e22151. [CrossRef] [PubMed]

150. Masaki, C.; Sharpley, A.L.; Cooper, C.M.; Godlewska, B.R.; Singh, N.; Vasudevan, S.R.; Harmer, C.J.; Churchill, G.C.; Sharp, T.; Rogers, R.D.; et al. Effects of the potential lithium-mimetic, ebselen, on impulsivity and emotional processing. Psychopharmacology 2016, 233, 2655-2661. [CrossRef]

151. Barkus, C.; Ferland, J.-M.N.; Adams, W.K.; Churchill, G.C.; Cowen, P.J.; Bannerman, D.M.; Rogers, R.D.; Winstanley, C.A.; Sharp, T. The putative lithium-mimetic ebselen reduces impulsivity in rodent models. J. Psychopharmacol. 2018, 32, 1018-1026. [CrossRef] [PubMed]

152. Singh, N.; Serres, F.; Toker, L.; Sade, Y.; Blackburn, V.; Batra, A.S.; Saiardi, A.; Agam, G.; Belmaker, R.H.; Sharp, T.; et al. Effects of the putative lithium mimetic ebselen on pilocarpine-induced neural activity. Eur. J. Pharmacol. 2020, 883, 173377. [CrossRef]

153. Fenn, G.D.; Waller-Evans, H.; Atack, J.R.; Bax, B.D. Crystallization and structure of ebselen bound to Cys141 of human inositol monophosphatase. Acta Crystallogr. Sect. F Struct. Biol. Commun. 2020, 76, 469-476. [CrossRef] [PubMed]

154. Sharpley, A.L.; Williams, C.; Holder, A.A.; Godlewska, B.R.; Singh, N.; Shanyinde, M.; MacDonald, O.; Cowen, P.J. A phase 2a randomised, double-blind, placebo-controlled, parallel-group, add-on clinical trial of ebselen (SPI-1005) as a novel treatment for mania or hypomania. Psychopharmacology 2020, 237, 3773-3782. [CrossRef]

155. Antoniadou, I.; Kouskou, M.; Arsiwala, T.; Singh, N.; Vasudevan, S.R.; Fowler, T.; Cadirci, E.; Churchill, G.C.; Sharp, T. Ebselen has lithium-like effects on central 5-HT 2A receptor function. Br. J. Pharmacol. 2018, 175, 2599-2610. [CrossRef] [PubMed]

156. Fuentes-López, E.; García-Huidobro Nuñez, F.; Acuña Caro, P.; Castro Becerra, N.; Jalil García, G.; Molina Marín, N.; Navea Stuardo, L.; Magallón, E.; Badía Venti, P. Auditory effects of recreational and occupational noise exposure among dental students: A cross-sectional study. Rev. CEFAC 2021, 23, 1-9. [CrossRef]

157. Ohlemiller, K.K.; McFadden, S.L.; Ding, D.-L.; Lear, P.M.; Ho, Y.-S. Targeted Mutation of the Gene for Cellular Glutathione Peroxidase (Gpx1) Increases Noise-Induced Hearing Loss in Mice. J. Assoc. Res. Otolaryngol. 2000, 1, 243-254. [CrossRef]

158. Kil, J.; Pierce, C.; Tran, H.; Gu, R.; Lynch, E.D. Ebselen treatment reduces noise induced hearing loss via the mimicry and induction of glutathione peroxidase. Hear. Res. 2007, 226, 44-51. [CrossRef] [PubMed]

159. Pourbakht, A.; Yamasoba, T. Ebselen attenuates cochlear damage caused by acoustic trauma. Hear. Res. 2003, 181, 100-108. [CrossRef] 
160. Lynch, E.D.; Gu, R.; Pierce, C.; Kil, J. Ebselen-Mediated Protection From Single and Repeated Noise Exposure in Rat. Laryngoscope 2004, 114, 333-337. [CrossRef]

161. Lee, M.Y.; Kabara, L.L.; Swiderski, D.L.; Raphael, Y.; Duncan, R.K.; Kim, Y.H. ROS Scavenger, Ebselen, Has No Preventive Effect in New Hearing Loss Model Using a Cholesterol-Chelating Agent. J. Audiol. Otol. 2019, 23, 69-75. [CrossRef] [PubMed]

162. Kil, J.; Lobarinas, E.; Spankovich, C.; Griffiths, S.K.; Antonelli, P.J.; Lynch, E.D.; Le Prell, C.G. Safety and efficacy of ebselen for the prevention of noise-induced hearing loss: A randomised, double-blind, placebo-controlled, phase 2 trial. Lancet 2017, 390, 969-979. [CrossRef]

163. Gu, R.; Longenecker, R.J.; Homan, J.; Kil, J. Ebselen attenuates tobramycin-induced ototoxicity in mice. J. Cyst. Fibros. 2021, 20, 271-277. [CrossRef]

164. Leroux, F.; Bosc, D.; Beghyn, T.; Hermant, P.; Warenghem, S.; Landry, V.; Pottiez, V.; Guillaume, V.; Charton, J.; Herledan, A.; et al. Identification of ebselen as a potent inhibitor of insulin degrading enzyme by a drug repurposing screening. Eur. J. Med. Chem. 2019, 179, 557-566. [CrossRef] [PubMed]

165. Kil, J.; Harruff, E.E.; Longenecker, R.J. Development of ebselen for the treatment of sensorineural hearing loss and tinnitus. Hear Res. 2021, 108209. [CrossRef] [PubMed]

166. Mochizuki, K.; Ohno, Y.; Kanematsu, T.; Sakurai-Yamashita, Y.; Niwa, M.; Hishikawa, Y.; Koji, T. Possible Protection of Sinusoidal Endothelial Cells by Endothelin B Receptor During Hepatic Warm Ischemia-Reperfusion. Surg. Today 2007, 37, 460-467. [CrossRef]

167. Cheng, B.; Zhong, J.; Wu, F.; Li, G.; Ruan, Q.; Luo, G.; Jiang, H. Ebselen protects rat hearts against myocardial ischemia-reperfusion injury. Exp. Ther. Med. 2018. [CrossRef] [PubMed]

168. Beckman, J.A.; Goldfine, A.B.; Leopold, J.A.; Creager, M.A. Ebselen does not improve oxidative stress and vascular function in patients with diabetes: A randomized, crossover trial. Am. J. Physiol. Heart Circ. Physiol. 2016, 311, H1431-H1436. [CrossRef]

169. Zhang, W.; Zhu, M.; Wang, F.; Cao, D.; Ruan, J.J.; Su, W.; Ruan, B.H. Mono-sulfonated tetrazolium salt based NAD(P)H detection reagents suitable for dehydrogenase and real-time cell viability assays. Anal. Biochem. 2016, 509, 33-40. [CrossRef] [PubMed]

170. Yu, Y.; Jin, Y.; Zhou, J.; Ruan, H.; Zhao, H.; Lu, S.; Zhang, Y.; Li, D.; Ji, X.; Ruan, B.H. Ebselen: Mechanisms of Glutamate Dehydrogenase and Glutaminase Enzyme Inhibition. ACS Chem. Biol. 2017, 12, 3003-3011. [CrossRef] [PubMed]

171. Jin, Y.; Li, D.; Lu, S.; Zhao, H.; Chen, Z.; Hou, W.; Ruan, B.H. Ebselen Reversibly Inhibits Human Glutamate Dehydrogenase at the Catalytic Site. Assay Drug Dev. Technol. 2018, 16, 115-122. [CrossRef] [PubMed]

172. Węglarz-Tomczak, E.; Burda-Grabowska, M.; Giurg, M.; Mucha, A. Identification of methionine aminopeptidase 2 as a molecular target of the organoselenium drug ebselen and its derivatives/analogues: Synthesis, inhibitory activity and molecular modeling study. Bioorg. Med. Chem. Lett. 2016, 26, 5254-5259. [CrossRef]

173. Chen, Z.; Jiang, Z.; Chen, N.; Shi, Q.; Tong, L.; Kong, F.; Cheng, X.; Chen, H.; Wang, C.; Tang, B. Target discovery of ebselen with a biotinylated probe. Chem. Commun. 2018, 54, 9506-9509. [CrossRef] [PubMed] 